
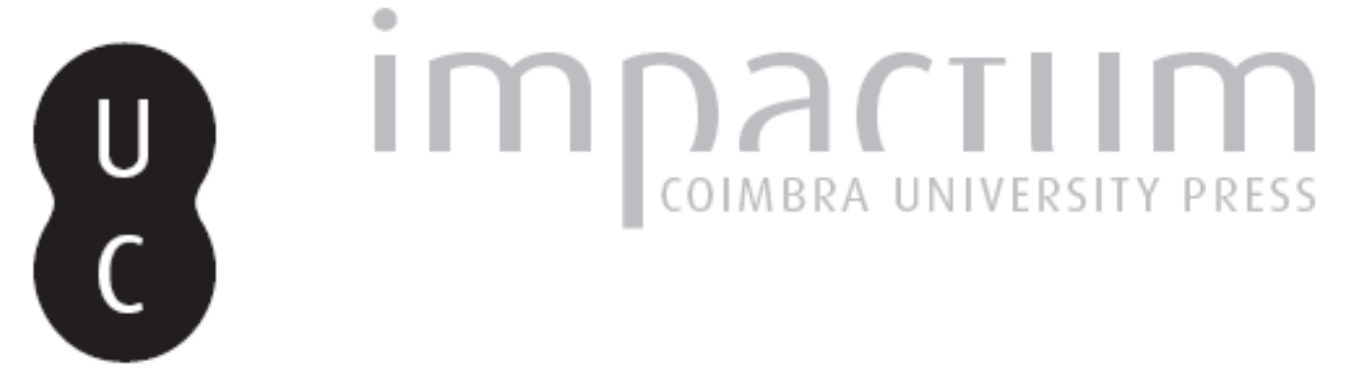

\title{
Os dominicanos e a cultura em tempos medievais: o caso português
}
Autor(es):
Gomes, Saul António
Publicado por: Faculdade de Letras da Universidade de Coimbra
URL persistente:
URI:http://hdl.handle.net/10316.2/32759
DOI:
DOI:http://dx.doi.org/10.14195/0870-4112_7_12
Accessed : $\quad$ 26-Apr-2023 16:15:12

A navegação consulta e descarregamento dos títulos inseridos nas Bibliotecas Digitais UC Digitalis, UC Pombalina e UC Impactum, pressupõem a aceitação plena e sem reservas dos Termos e Condições de Uso destas Bibliotecas Digitais, disponíveis em https://digitalis.uc.pt/pt-pt/termos.

Conforme exposto nos referidos Termos e Condições de Uso, o descarregamento de títulos de acesso restrito requer uma licença válida de autorização devendo o utilizador aceder ao(s) documento(s) a partir de um endereço de IP da instituição detentora da supramencionada licença.

Ao utilizador é apenas permitido o descarregamento para uso pessoal, pelo que o emprego do(s) título(s) descarregado(s) para outro fim, designadamente comercial, carece de autorização do respetivo autor ou editor da obra.

Na medida em que todas as obras da UC Digitalis se encontram protegidas pelo Código do Direito de Autor e Direitos Conexos e demais legislação aplicável, toda a cópia, parcial ou total, deste documento, nos casos em que é legalmente admitida, deverá conter ou fazer-se acompanhar por este aviso.
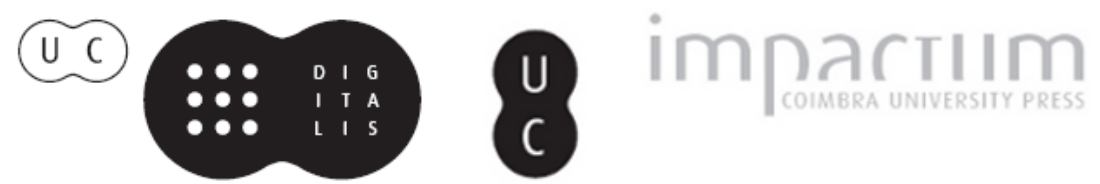


\section{Sociedade em Tumulto}

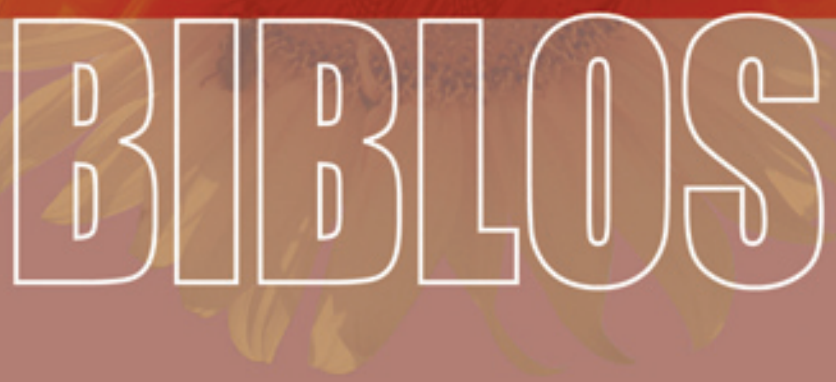

REVISTA DA FACULDADE DE LETRAS

UNIVERSIDADE DE GOIMBRA 
Biblos, n. s. VII (2009) 261-294

Saul António Gomes

(Universidade de Coimbra)

\section{OS DOMINICANOS E A CULTURA EM TEMPOS MEDIEVAIS: O CASO PORTUGUÊS ${ }^{1}$}

\section{RESUMO}

Este estudo propõe-se avaliar o quadro cultural que caracterizou a presença dos frades dominicanos em Portugal durante os tempos medievais. Depois de debater a dimensão plural do universo dominicano, o autor procede à análise do significado político-cultural da presença destes mendicantes em Portugal, examina a relevância das figuras dos provinciais Fr. Soeiro Gomes e Fr. Gil de Santarém, avalia os conteúdos das bibliotecas existentes nos seus conventos e a sobrevivência de manuscritos medievais dominicanos em arquivos e bibliotecas actuais. Considera-se, ainda, o peso dos intelectuais na Ordem e na história da Universidade portuguesa e, finalmente, o contributo da espiritualidade dominicana na religiosidade portuguesa.

Palavras-chave: Idade Média, Mendicantes, Portugal.

\section{Abstract}

This study aims to consider the cultural framework which structured the activities of Dominican friars in Portugal during the Middle Ages. After discussing the question of the plural relevance of the Domicans' world, the author analyzes the political and cultural significance of these mendicant friars in Portugal, examines the historical role of the provincials Fr. Soeiro Gomes and Fr. Gil de Santarém, and focuses on the constitution of monastic libraries at that time and on the survival of medieval Dominican manuscripts in archives and libraries in our day. The author also addresses the question of the influence that Dominican intellectuals had on the history of the Portuguese university and, finally, the spiritual contribution of Dominicans to Portuguese religiosity. Keywords: Middle Ages, Mendicant friars, Portugal.

\footnotetext{
${ }^{1} \mathrm{O}$ texto que se edita serviu parcialmente de base à comunicação por nós apresentada ao Congresso Internacional "Os Dominicanos em Portugal”, celebrado na Fac. Letras da Universidade Porto, e Museu Nacional Soares dos Reis, Porto, 14-16 de Dezembro de 2006. 


\section{1 - Níveis e categorias culturais plurais na história da Ordem dos Pregadores.}

Será um lugar-comum, mas ainda assim útil ao nosso intento, começar, esta intervenção, recordando que a Ordem dos Frades Pregadores sempre se caracterizou pela elevação em que teve, desde os seus primórdios, as questões educacionais e o nível cultural erudito dos seus elementos. Mau grado a leveza e a pouca originalidade com que se recorre a esta caracterização da Ordem de S. Domingos, ela não deixa de ser, cremos, uma visão ajustada à identidade histórica deste universo religioso mendicante. Mas esta leitura, naturalmente, não pode ser entendida como um estereótipo, como uma impressão fixa e rígida.

$\mathrm{Na}$ verdade, não devemos encarar a vida cultural e espiritual dominicana, seja nos tempos medievais, seja nos séculos posteriores, como um todo absolutamente homogéneo. Se, de um ponto de vista institucional e administrativo, muito há a unir os conventos dominicanos por toda a Europa medieva - princípio identitário que salvaguarda a unidade plurissecular da Ordem -, a verdade é que não podemos deixar de reconhecer que, nesse extenso território dos frades pregadores, há lugar para a diversidade e para a diferenciação cultural.

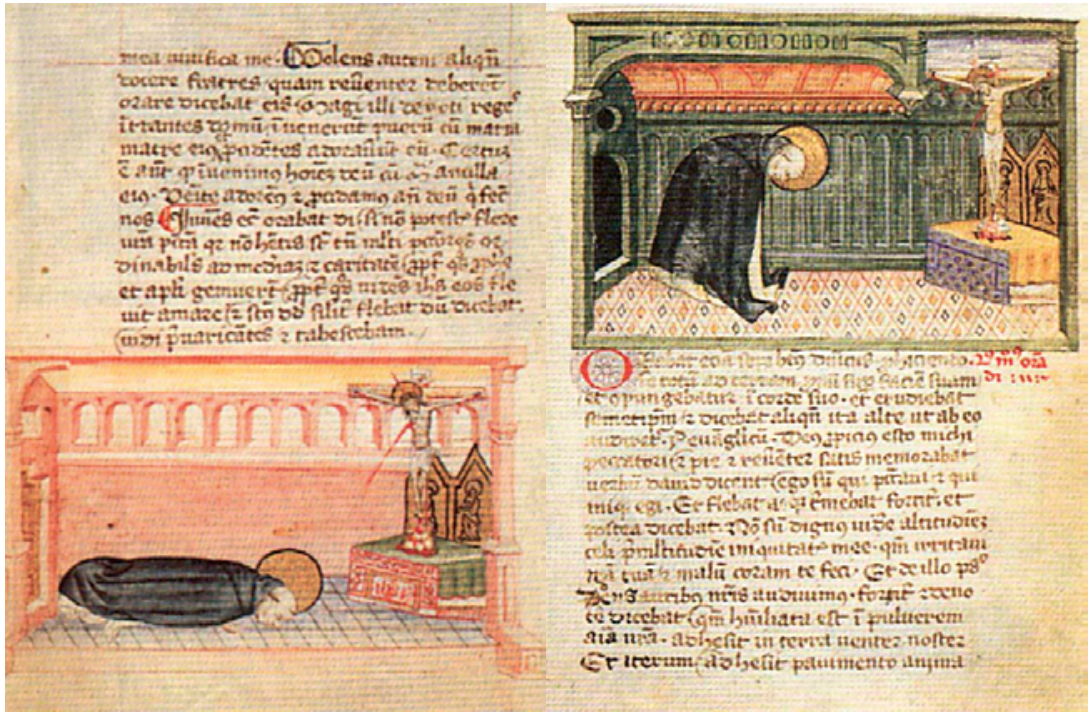

Primeiro e segundo modo de orar de S. Domingos

(Roma, Bibl. Vaticana - Codex Rossianus, 3) 
Nem todos os conventos, naturalmente, tinham condições para concentrarem boas ou extensas bibliotecas, especialmente se pensarmos em livrarias especializadas em áreas como a Teologia, o Direito ou mesmo a Hagiografia e a Homilética, assim como se diferenciavam entre eles pela população de professos e de conversos que captavam ou pelas propostas artísticas que a sua indispensável monumentalidade e imaginários devocionais protagonizavam. Devemos lembrar que falamos de culturas diferentes, ainda, quando encaramos as clausuras masculinas e as femininas, os modelos de formação sacerdotal e de actuação pastoral dos professos se encarados na longa diacronia do processo histórico, verificando-se, em última análise, a diversidade de que falamos ao examinarmos os exemplos de vidas veneráveis e mesmo de santidade protagonizados pelas gerações dominicanas.

Os Capítulos Gerais da Ordem, desde 1220, aprovarão modelos de oração comuns e princípios litúrgicos uniformes, ao mesmo tempo em que incentivam a escrita de uma história dominicana e da sua memória espiritual. Com tal actuação, a Ordem dos Frades Pregadores logrou resistir de modo muito efectivo e, aparentemente, sem grandes fracturações internas, a intempéries e adversidades históricas.

Os níveis culturais experienciados entre as comunidades dominicanas, naturalmente, variavam, posto que, em geral, quando falamos de frades pregadores em tempos de Medievo, estejamos perante uma ecúmena culturalmente bem apetrechada e espiritualmente rica.

De todo o modo, há que reconhecer que o saber e a arte da pregação, que tanto motivavam os frades pregadores, desde os primórdios da Ordem, exigiam uma formação intelectual mais específica, privilegiada e cimeira no quadro da vida cultural desta como de qualquer outra Ordem Religiosa medieva. Não é sem significado que S. Domingos desperta vocações entre públicos altamente escolarizados, caso dos das escolas catedralícias - de que ele próprio era o exemplo primordial... - e de alguns studia monásticos, como sobremodo nos meios universitários e entre os grupos sociais urbanos de maior literacia. Lembremos que as Constituições de 1220 admitem o ingresso nos claustros conventuais domínicos a partir dos quinze anos de idade e sob condição dos postulantes dominarem minimamente as letras mais triviais.

\section{2 - Significado político-cultural da presença dominicana em Portugal.}

Os dominicanos assumem, desde os seus primórdios em terra portuguesa, uma clara disponibilidade para a intervenção em matéria 
política e também para a intermediação de conflitos jurídico-forenses. Frequentemente, aliás, estes dois sectores concorrem em causas comuns. Esse binómio político e jurídico é intrínseco, anotemo-lo, à posição dominicana centro-europeia, como se demonstra pela aproximação entre o Papado e os primeiros pregadores chefiados por Domingos de Gusmão. Verifica-se, efectivamente, que os frades seguidores daquele que viria a ser S. Domingos, souberam granjear, desde os seus inícios, o respeito e a consideração quer da sociedade eclesiástica, em especial, quer do mundo laical, em geral, esferas sociais que reconheciam nos claustros dominicanos uma garantia de competência jurídica, pelo menos a suficiente para lhes confiarem a guarda dos seus interesses e a resolução das suas causas e problemas jurídicos².

Lembremos que Fr. Soeiro Gomes, aparentemente, interferiu em matéria governativa da alçada régia portuguesa. Referimo-nos à conhecida questão dos seus "decretos laicales" - quiçá texto motivado por intenções evangelistas e cruzadísticas contra heresias, na linha, pois, do exemplo de mendicância apostólica e pregadora do próprio S. Domingos em terras do Languedoc e itálicas - que mereceram a denúncia e reprovação da cúria régia de D. Afonso $\mathrm{II}^{3}$. Pouco depois, encontraremos frades dominicanos e franciscanos envolvidos na questão política da deposição de D. Sancho II e da entronização do novo rei D. Afonso III. Lembre-se que foi aos Bispos de Coimbra e do Porto e ao "Prior Praedicatorum Colimbriensium" que Inocêncio IV, depois de uma admoestação veiculada pelos mesmos interlocutores, de 20 de Março de 1245, encarregou de publicarem, em Portugal, a bula Grandi non immerito, assinada justamente na próspera cidade de Lyon, a 25 de Julho de 1246, a qual depunha o rei D. Sancho II ${ }^{4}$.

Assumirão, ainda, século e meio mais tarde, enorme relevância histórica as posições dos sucessores de S. Domingos na causa do Mestre de Avis. Encontraremos presentes ao auto de eleição e proclamação do Rei D. João I, lavrado em Coimbra, a 6 de Abril de 1385, os pregadores

${ }^{2}$ Cf. Paul Bertrand, Commerce avec dame Pauvreté. Structures et fonctions des couvents mendiants à Liège (XIII ${ }^{e}-X I V^{e}$ s.), Genève, Librairie Droz, 2004, pp. 365-378.

${ }^{3}$ Vd. Francisco da Gama Caeiro, "Os primórdios dos frades pregadores em Portugal. Enquadramento histórico-cultural" e "Sobre heresias medievais: em torno dos "decretos" de Sueiro Gomes", in Dispersos, Vol. III, Lisboa, Imprensa Nacional - Casa da Moeda, 1999, pp. 419-436 e 449-460, respectivamente.

${ }^{4}$ D. António Caetano de Sousa, Provas da História Genealogica da Casa Real Portugueza, (Ed. De M. Lopes de Almeida e de César Pegado), Tomo I, Livro III, Coimbra, Atlântida, 1947, pp. 57--61. 
Fr. Lourenço Lampreia e Fr. Domingos de Aveiro, assim se assinalando a activa presença de membros da Ordem na causa portuguesa no contexto da Crise de 1383-1385 .

D. João I, aliás, como liberal senhor que gostava de retribuir serviços e lealdades, cumularia a vigararia portuguesa da Ordem de consideráveis benefícios, como podemos avaliar muito bem pelo facto deste monarca lhes ter doado o Mosteiro da Batalha e o de Benfica e de, em 1418, se estabelecer canonicamente a Província Portuguesa da Ordem, assistindo-se, desde então e por toda a Centúria de quatrocentos, a uma multiplicação das fundações dos Pregadores dentro do Reino e mesmo em território luso-magrebino.

No preâmbulo da doação aos frades de S. Domingos do Mosteiro de Santa Maria da Vitória, em 4 de Abril de 1388, declara D. João I, num significativo elogio tradutor de uma complexa e sensível adesão à estética própria da liturgia e da espiritualidade dominicanas medievas portuguesas, ter tomado tão generosa opção:

"Por honrra da Virgem Maria nosa defensor e destes regnos consirando as muitas e stremadas graças que do seu Filho bento a rogo della sempre recebemos assy em guarda do nosso corpo como em exalçamento dos dictos regnos e em as guerras e mesteres em que somos poostos specialmente na batalha e campo que ouvemos com os castellãaos dando nos delles victoria maravilhosa mais por a sua misericordia que por os nossos merecimentos, preposemos em relenbrança de beneficios per ella recebidos de edificar e mandar fazer casa de oraçam em a qual honrra e louvor da dicta Senhora se faça serviço a Deus a qual de fecto ja mandamos começar a par da Canueira porque segundo Deus e verdade os frades pregadores da hordem de Sam Domingos som mui devotos em ella assy por as suas obras como pollo abito que de suas mãaos receberam e som outrossy merecedores de todo bem e mais que a nosso Senhor e a dicta Senhora sua madre servem em cada huum dia e saberam servir ao diante, rogando a elles por nos e pollos dictos regnos(...)"'.

Por ocasião da doação dos paços para a fundação de S. Domingos de Benfica, em 1398, D. João I insiste novamente na relevância que a Ordem de S. Domingos assumia junto de si e dos seus cortesãos mais

${ }^{5}$ D. António Caetano de Sousa, Op. cit., pp. 2-19: 10-11 e 19.

${ }^{6} \mathrm{~S}$. A. Gomes, Fontes Históricas e Artísticas do Mosteiro e da Vila da Batalha (Séculos XIV a XVII), Vol. I, Lisboa, IPPAR, 2000, Doc. 1.

Faculdade de Letras | Universidade de Coimbra 
próximos, reiterando que assinava tal concessão: "por amor de Deus e a rogo do doutor Joham das Regas do nosso conselho damos e doamos e fazemos livre e pura doaçam deste dia pera todo sempre a hordem de Sam Domingos dos nossos paaços de Bemfica da par da cidade de Lixboa com todos seus pumares e ortas e entradas e saidas pera se fazer delles huum moesteiro e starem hi frades a serviço de Deus"7.

Recordaremos, ainda, que foi na Capela de Jesus do Mosteiro de S. Domingos de Lisboa que o rei D. Manuel I, em 7 de Março de 1499, "sendo S. Alteza presente ["dentro em sua cortina (...) assentado em sua cadeira baixa posta so o estrado"], e os Tres Estados de seu Reino", acabada a Missa e vésperas que disse D. Diogo de Ortiz, bispo de Tânger, proferida a oração e arenga em louvor de obediência pelo Licenciado Pedro de Gouveia, foi jurado D. Miguel da Paz por príncipe herdeiro dos Reinos de Portugal e do Algarve ${ }^{8}$.

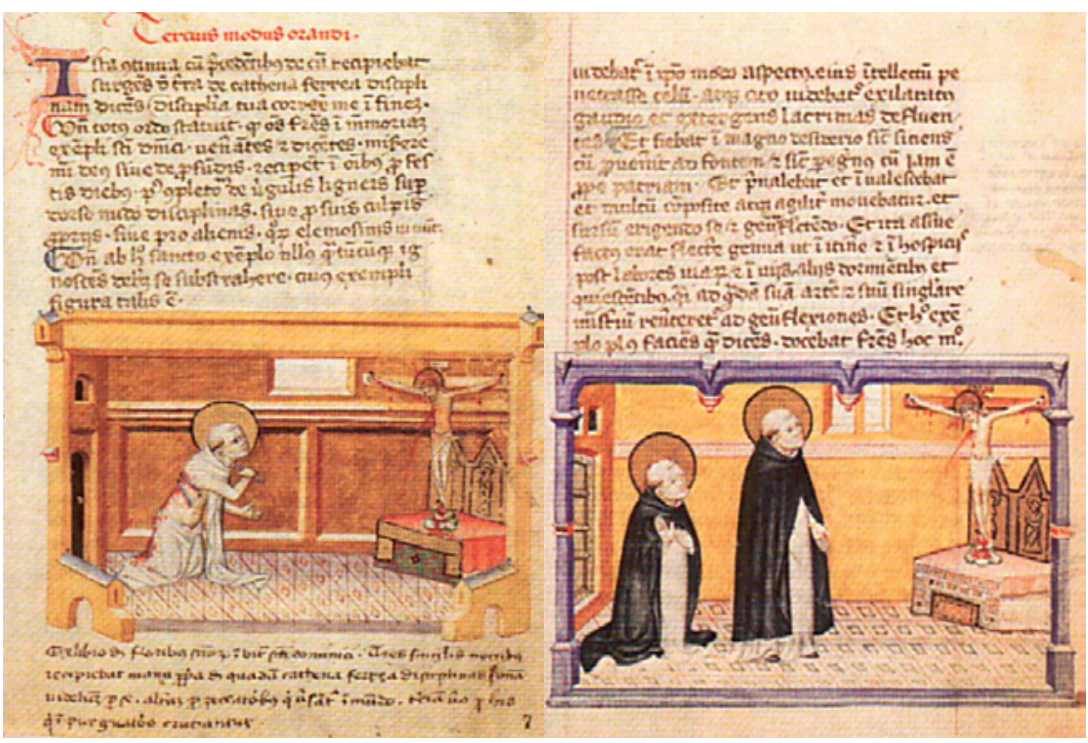

Terceiro e quarto modos de orar de S. Domingos

(Roma, Bibl. Vaticana - Codex Rossianus, 3)

${ }^{7}$ Chancelarias Portuguesas. D. João I (Org. de João José Alves Dias), Vol. I, Tomo I, (1384-1385), Lisboa, Centro de Estudos Históricos da Universidade Nova de Lisboa, 2004, Doc. 1468.

${ }^{8}$ D. António Caetano de Sousa, Provas de Historia Genealogica..., Tomo II, pp. 493-497.

Faculdade de Letras | Universidade de Coimbra 


\section{3 - Relevância histórico-cultural dos provincialatos de Fr. Soeiro Gomes e de Fr. Gil de Santarém.}

Incumbido do cargo de prior-provincial da Hispania, Fr. Soeiro Gomes recebe de D. Fernando III de Castela e Toledo, a 18 de Junho de 1222, garantia de protecção e de apoio para as fundações que intentasse nesses Reinos ${ }^{9}$. Acolhia, assim, o monarca castelhano a solicitação do Papa Honório III, proclamada em Viterbo, a 15 de Novembro de 1219, pela qual se avocavam todos os prelados da Igreja católica, mormente a da Hispania, a honrarem e favorecerem o acolhimento dos dominicanos nos territórios em que presidiam espiritualmente ${ }^{10}$.

Terá sido na sequência desta ou de outras bulas pontifícias de Honório III que, em Portugal, alguns bispos virão a manifestar a sua pronta solicitude ao desígnio papal. Conhece-se, efectivamente, a pronta predisposição de D. Pedro Soares, ordinário de Coimbra, para acolher na sua Diocese os novos religiosos:

"Concessimus et concedimus", escreveu este bispo conimbricense,

"Domno Suerio de Ordine Praedicatorum Priori, et omnibus suis Fratribus, licentiam praedicandi per totum Colimbriensem Episcopatum. Et adhuc concedimus ei licentiam et potestatem compellendi et corrigendi omnes excessus, quatenus Dei gratia, vos omnes per eorum praedicationem melius et facilius ad fidem Catholicam vos valeant perducere. Et etiam addimus, quod ipsi vobis concedant absolutionem peccatorum vestrorum quadraginta dierum; de illis dicimus, qui ad praedicationem eorum venerint, et eos benigne audierint, et eorum praedicationem exaudierint." 11

Conjuga-se o acto de D. Pedro Soares com a linguagem dos diplomas pontifícios pertinentes aos novos frades, insistindo na nomenclatura da "Ordine Praedicatorum" e da sua organicidade. Sabemos, contudo, que o vocabulário jurídico-canónico oriundo da esfera pontifícia, acolhido pelas chancelarias episcopais, quaisquer que fossem, demorou o seu

${ }^{9}$ Fr. Luís de Sousa, História de S. Domingos (Ed. de Manuel Lopes de Almeida, Porto, Lello \& Irmão, 1977 [doravante citado por História de S. Domingos], Parte I, Livro I, Cap ${ }^{\circ}$ XIX, pp. 98-99.

${ }^{10}$ História de S. Domingos, Parte I, Livro I, Cap ${ }^{\circ}$ XVIII, p. 97.

${ }^{11}$ História de S. Domingos, Parte I, Livro I, Cap ${ }^{\circ}$ XVI, p. 83. 
tempo a incorporar-se na linguagem comum dos fideles Ecclesiae mesmo entre as elites sociais mais letradas ${ }^{12}$.

Em Portugal, contudo, a documentação disponível para conhecer o dealbar do movimento dominicano aqui chegado, parece indicar que este assumiu rapidamente uma acentuada carga institucional. A experiência de Montejunto poderá ter sido refractária à esfera central da ideia e da proposta domínicas, ab initio, como referíamos, apostada numa elocução acentuadamente jurídico-institucional.

Não estranhará, assim, que na concórdia estabelecida entre D. Sancho II e D. Estêvão Soares, o poderoso arcebispo bracarense, lavrada em Coimbra, no mês de Junho de 1223, e intermediada pela judicatura presidida justamente pelo nosso Fr. Soeiro Gomes, por D. Garcia Mendes, arcediago de Braga e por D. Fernando Peres, que fora chantre da Sé de Lisboa - o piedoso, acrescentemos, fundador do Mosteiro de S. Paulo de Almaziva, da Ordem de Cister, levantado nos arredores de Coimbra, depois professo ao hábito dominicano, com o qual faleceria em provecta idade ${ }^{13}-$, o prior-provincial de S. Domingos na Hispania seja citado precisamente como "Domini Suerii Prioris Fratrum Praedicatorum in Hispania", omitindo-se o trivial "frater" ou, ainda, a nomenclatura da "Ordinem Praedicatorum", substituída antes pela noção forte dos "Fratrum Praedicatorum in Hispania" 14 .

Também em Maio de 1228, no Mosteiro de Arouca, Martinho Peres, notário da rainha D. Mafalda, regista, em contrato de escambo feito com aquele cenóbio por certa Teresa Eanes, terem sido testemunhas presentes diante da "Regine Domne Maphalde", os senhores "Domni Suerii Gomecii predicatoris et fratris Martini predicatoris et fratris Egidii conuersis et domne Marie Laurentii tum temporis de Arauce abbatisse." 15 Pensamos que se trata justamente de Fr. Soeiro Gomes, de um seu companheiro, Fr. Martinho e, eventualmente, de um irmão a eles associado, Fr. Gil, com o estatuto de converso.

${ }^{12}$ Vd. Luigi Caneti, "Intorno all' "idolo delle origini". La storia dei primi frati Predicatori”, in I frati predicatori nel Duecento (Cura G. G. Merlo), Verona, Col. "Quaderni di storia religiosa", III, 1996, pp. 9-51.

${ }^{13}$ Vd. História de S. Domingos, Parte I, Livro II, Cap ${ }^{\circ}$ VI, pp. 159-161; Maria José Azevedo Santos, Vida e Morte de um Mosteiro Cisterciense- S. Paulo de Almaziva - Séculos XIII-XVI, Lisboa, Edições Colibri, 1998.

${ }^{14}$ História de S. Domingos, Parte I, Livro I, Cap ${ }^{\circ}$ XXI, p. 107.

${ }^{15} \mathrm{TT}$ - Mosteiro de Pendorada, $\mathrm{M}^{\mathrm{o}} 15$, doc. não numerado. 
Parece-nos importante anotar esta coincidente proximidade, sobremaneira pastoral e espiritual, dos primeiros fratres predicatores dos ambientes cistercienses portugueses, assim como acontecera já no percurso emergente da experiência religiosa de Domingos de Gusmão enquanto pregador e fundador de um ordo praedicatorum. Aliás, como Domingos que fora cónego da catedral de Osma, cuja cultura e espiritualidade o levaram a aproximar-se de um ideal monástico reformado e mendicante, também em Portugal se regista uma particular atracção das comunidades catedralícias pelas células conventuais dominicanas. O Livro das Kalendas da Sé de Coimbra revela-nos a opção de vários cónegos dessa catedral por se fazerem sepultar em claustros dominicanos de Coimbra e de Santarém ${ }^{16}$. Não era invulgar, aliás, encontrar-se pregadores de S. Domingos no púlpito da Sé coimbrã em dias festivos ${ }^{17}$. Na cidade do Porto, a instalação dos Dominicanos, em 1239, conheceu, inicialmente, a oposição do Bispo D. Pedro Salvadores e do seu Cabido, mas a protecção dispensada pela Infanta D. Mafalda, recolhida em Arouca, ao intento protagonizado pelo provincial Fr. Gil de Santarém, permitiu ultrapassar essa animadversão ${ }^{18}$.

E não é apenas essa proximidade que importa relevar neste ponto, pois que a poderemos defender em matéria de opções de género fundacional. Entendamo-nos melhor. Assim como em Toulouse o acontecimento marcante de Prouille (1206) e, mais tarde, em Roma, a fundação das monjas de Santo Sisto (1221) impõe reconhecermos a importância carismática e precursora que o futuro $\mathrm{S}$. Domingos concedeu ao protagonismo religioso feminino no seio do seu modelo espiritual ${ }^{19}$, também em Portugal assistiremos a

${ }^{16}$ Maria Helena da Cruz Coelho e João José da Cunha Matos, "O Convento velho de S. Domingos de Coimbra (Contributo para a sua história)", in Arquivo Histórico Dominicano Português, Vol. III/2, Porto, 1986, pp. 4-7.

${ }^{17}$ Maria Helena da Cruz Coelho, "A cidade de Coimbra sob ameaça de interdito", in Revista de História das Ideias. Vol. 22 (2001). O Estado e a Igreja. Homenagem a José Antunes, Coimbra, pp. 51-69.

${ }^{18} \mathrm{Vd}$. Humberto Baquero Moreno, "O fornecimento de água ao Convento de S. Domingos do Porto nos séculos XIV e XV", in Boletim do Arquivo Distrital do Porto, Vol. II, Porto, Instituto Português do Património Cultural, 1985, pp. 57-70.

${ }^{19}$ Vd. M.-H. Vicaire, Saint Dominique et ses frères. Évangile ou Croisade?, Paris, Cerf, 1967, pp. 68, 154-155; Idem, Histoire de saint Dominique. Vol 1. Un homme 
atitude próxima, em torno de S. Félix e Santo Adriano de Chelas, junto a Lisboa ${ }^{20}$.

Comunidade masculina por $1192 \mathrm{e}$, ainda, em 1219, ao que parece hospitalária, vemo-la feita casa de monjas já antes de Março de 1229, data do compromisso de profissão de Domingas Rodrigues, vizinha de Santarém, "sensumeo considerans statum mundi, etmeum, et praecauens in futurum, ad honorem Dei et ordinis Sancti Dominici do et concedo, et roboro corpus meum et animan in Monasterio Dominarum de Achellis in earundem Ordinem, sumpto eiusdem Ordinis habitu, in vita et in morte in perpetuum permansuram." Acto de relevo, a que deram fé Fr. Paio de Braga, Fr. Pedro Soares de Lisboa, Fr. Domingos Martins de Lisboa e João Eanes da Ribeira, "quondam procurator dominarum"21, decerto companheiros de hábito de Fr. Soeiro Gomes.

Este testemunho, como ainda as bulas pontifícias de Gregório IX, Prudentibus virginibus, de 1234 e de Clemente IV, de 21 de Fevereiro de 1266, afirmam categoricamente as raízes dominicanas desta comunidade feminina dos arredores de Lisboa, posto que, por esta última carta apostólica, se indicie a cessação da ligação desta clausura à obediência, visitação e jurisdição dos Dominicanos, desacordados com o "perigo" e com a "liberdade nociva" a que as donas deste claustro intentavam inclinadas, preferindo a obediência mais suave dos bispos olisiponenses, consumando-se a cisão em 1295, falecida a prioresa D. Teresa Fagundes. De Chelas, aliás, saíram monjas para a fundação, em 1240, do Mosteiro das Donas de Santarém ${ }^{22}$.

Fr. Soeiro Gomes desenvolverá uma notabilíssima acção em favor da Ordem em toda a Península Ibérica. Teve correspondência com o conhecido Fr. Raimundo de Penhaforte, referindo-se-lhe o religioso catalão no prólogo da sua Summa de Casos, com significativa dedicatória: "Reverendo et beatissimo Patri in Christo Fratri Gometio Priori Fratrum Ordinis Praedicatorum in Hispania" 23 . Falecido em 1233, ano da solene trasladação do corpo de S. Domingos, em Bolonha, Fr. Soeiro Gomes contava doze anos à cabeça da província da Hispania, sucedendo-lhe

évangélique, Paris, Cerf, 1982, pp. 241-258; Idem, Dominique et ses prêcheurs, Paris, Cerf, 1977, passim.

${ }^{20} \mathrm{Vd}$. Maria Filomena Andrade, O Mosteiro de Chelas. Uma comunidade feminina na Baixa Idade Média. Património e Gestão, Cascais, Patrimonia, 1996, pp. 17-27.

${ }^{21}$ História de S. Domingos, Parte I, Livro I, Cap ${ }^{\circ}$ XXIII, pp. 117-118.

${ }^{22}$ História de S. Domingos, Parte I, Livro I, Cap ${ }^{\circ}$ XXV, pp. 123-127.

${ }^{23}$ História de S. Domingos, Parte I, Livro I, Cap ${ }^{\circ}$ XXVIII, p. 138. 
no cargo um outro português, Fr. Gil de Santarém, exaltação que deixa reconhecer a relevância e o peso dos dominicanos portugueses desses anos no todo que era a Província Hispânica, berço natal do Fundador.

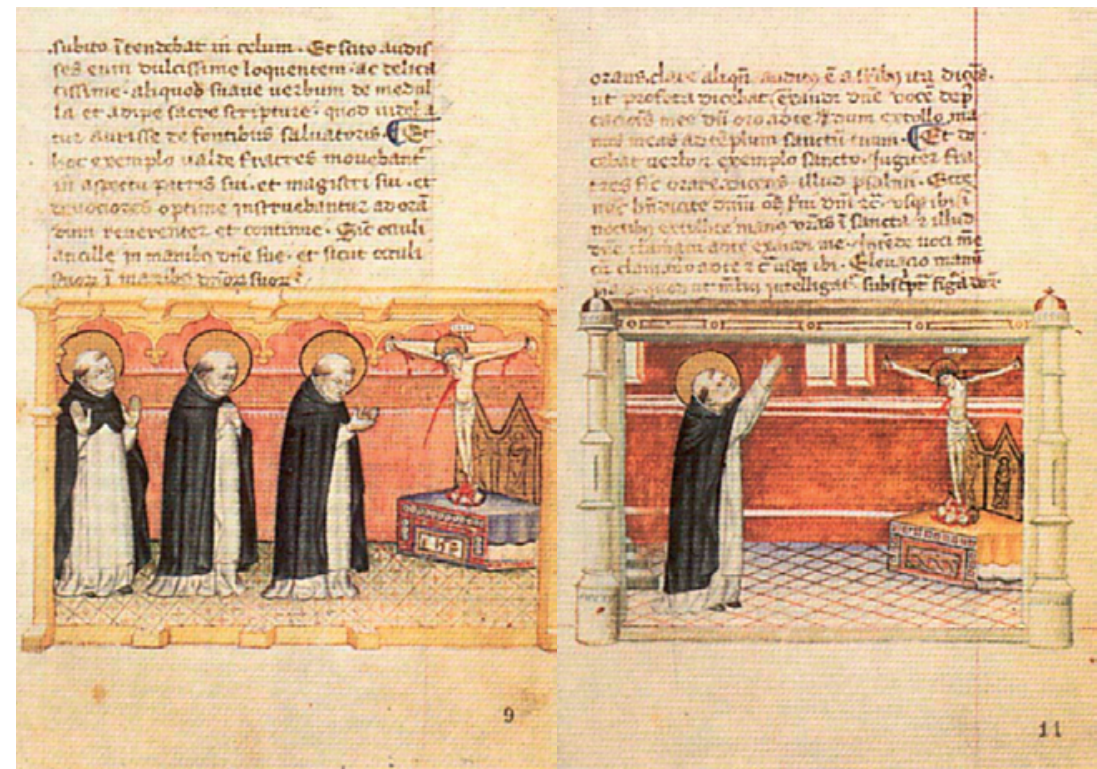

Quinto e sexto modos de orar de S. Domingos (Roma, Bibl. Vaticana - Codex Rossianus, 3)

Ingressaram na Ordem, neste provincialato de Fr. Soeiro Gomes, Fr. Pêro Gonçalves Telmo, Fr. Lourenço Mendes, de Guimarães, Fr. Gonçalo de Amarante, Fr. Gil de Santarém e Fr. Paio de Coimbra, religiosos venerados por bem-aventurados nos altares da devoção dominicana ${ }^{24}$. Devemos assinalar, também, a tradição históricohagiográfica preservada nos claustros dominicanos portugueses em torno de um considerável número de exemplos de santa vida protagonizada por irmãos leigos ou conversos, o que nos parece revelador do espaço oferecido pelas comunidades claustrais do tempo dos provinciais Fr. Soeiro Gomes e Fr. Gil de Santarém à partilha e mesmo protagonismo por agentes laicais irmanados no espírito domínico ${ }^{25}$.

${ }^{24}$ História de S. Domingos, Parte I, Livro I, $\mathrm{Cap}^{\circ}$ XXVIII, pp. 138-141.

${ }^{25}$ Cf. História de S. Domingos, Parte I, Livro II, Cap ${ }^{\text {s } ~ V I I-I X, ~ p p . ~ 161-167 ; ~ F r . ~}$ Gerardo de Frachet, O. P., As Vidas dos Irmãos (Tradução da edição crítica latina por 
Os Frades Pregadores estabelecem então as suas principais comunidades, a primeira dos quais foi certamente o Convento de Coimbra, solar futuro da dinâmica pastoral dominicana portuguesa dos plenos séculos medievos ${ }^{26}$. Coimbra com Santarém (em Montirás, ca. $1223^{27}$ ) e, logo depois, Porto (1238) e Lisboa (1241), serão as cidades de acolhimento das primeiras gerações dominicanas portuguesas. Pertencem já a uma segunda geração de frades os claustros de Elvas (1266), Guimarães (1270) e Évora (1286).

No último quartel de Trezentos, foram fundados dois novos grandes claustros dominicanos, o da Batalha (1388) e o de Benfica (1399), casas maiores no panorama do fim da Idade Média dominicana lusitana que conhecerá, em Quatrocentos, os Conventos de Aveiro (1423), Vila Real (1424), Azeitão (1435), Abrantes (1472) e Pedrógão Grande (1476). Conhece-se bastante pouco do estabelecimento dominicano de Ceuta, remetido a 1415. Aos conventos masculinos antes indicados, devemos acrescentar as casas femininas de Chelas de Lisboa (ca.1229), das Donas de Santarém (1240) e, somente um século ou mais depois, as de Vila Nova de Gaia (1345), S. Salvador de Lisboa (1392), Jesus de Aveiro (1456/61) e Santa Ana de Leiria (1494) ${ }^{28}$.

O reinado de D. Sancho II foi, como vemos, o período em que se institucionalizaram as fundações relevantíssimas de Santarém, Coimbra, Porto e Lisboa. Entre estas, o Convento de Coimbra parece-nos assumir um papel nuclear dominante. A centralidade geográfica do Convento de Coimbra e a sua relevância na gestão institucional da Ordem

Fr. Alberto Maria Vieira), Fátima, 1990, pp. 212, 286-289. Cf., ainda, como exemplo de memória onírica associada aos primórdios da Ordem em Portugal, as narrativas hagiográfica e diplomática que enformam o estabelecimento do Convento de S. Domingos de Lisboa. Vd. a elucidativa abordagem do caso devida a Antoine Thomas, La fondation du Couvent des Dominicains de Lisbonne (1241-1242). D'après l'histoire et d'après la légende, Coimbra, Imprensa da Universidade, 1932.

${ }^{26}$ Vd. Maria Helena da Cruz Coelho e João José da Cunha Matos, "O Convento velho de S. Domingos de Coimbra. (Contributo para a sua história) ", separata de Arquivo Histórico Dominicano Português, Vol. III/2, Porto, 1986; S. A. Gomes, "A igreja de S. Domingos de Coimbra em 1521", in Arquivo Coimbrão. Boletim da Biblioteca Municipal, Vol. XXXIX, Coimbra, 2006 [2007], pp. 377-396.

${ }^{27}$ História de S. Domingos, Parte I, Livro 2, Cap ${ }^{\circ}$ III, p. 148.

${ }^{28}$ Fr. António do Rosário, Pergaminhos dos Conventos Dominicanos. I Série: Elementos de interesse para o Estudo Geral Português, vol. IV, $\mathrm{n}^{\circ} 1$ de Arquivos de História da Cultura Portuguesa, Lisboa, Instituto de Alta Cultura, 1972, pp. 7-8.

Faculdade de Letras | Universidade de Coimbra 
justificarão, cremos, o facto de ter sido muito provavelmente nele que se celebrou o Capítulo Provincial de 1365, debaixo do provincialato de Fr. Fernando Rodrigues, facto raríssimo no historial dominicano hispano-português ${ }^{29}$.

\section{4 - Testemunhos acerca de bibliotecas dominicanas medievas portuguesas.}

"Auctoritates quae sumuntur de libris sacris sunt quasi arma", definiu o Capítulo provincial da Provença, em 1288, assim confirmando algo de extraordinariamente comum entre os seguidores de Domingos nos séculos medievais: o amor aos livros e ao estudo. Seria redundante repetir neste momento as renovadas e sempre reiteradas insistências que os Frades Pregadores dedicaram ao estudo das Sagradas Escrituras, à aprendizagem das línguas dos povos e regiões a evangelizar, dentre as quais, aliás, assomam o árabe e o hebraico, não sendo infrutífero, sequer desconhecido dos historiadores da Ordem, o empenho demonstrado por conventuais hispanos na iniciação à língua dos crentes islamitas, bem assim à leitura, conhecimento, comentário e disputa das matérias corânicas ${ }^{30}$.

Vimos já o quanto a acção de Fr. Soeiro Gomes parece posicioná-lo entre os que revelavam particular sensibilidade por assuntos jurídicos e legais. Esta dimensão jurisdicista da Ordem foi claramente assumida pelas primeiras gerações da Ordem, como o demonstra o exemplo mais acabado que é a vida e obra de S. Raimundo de Penhaforte ou, ainda, a avocação dos seus membros para presidirem ou alvitrarem judicativamente em causas forenses sobremodo na esfera canónica.

Santo Alberto Magno e o seu discípulo S. Tomás de Aquino constituirão já uma outra linha de formação cultural e intelectual, mais

${ }^{29}$ S. A. Gomes, "As Ordens Mendicantes na Coimbra Medieval: Notas e Documentos", in Lusitania Sacra, 2a Série (10), 1998, p. 207; Idem, "Clérigos Regulares nas Ordenações Sacras da Sé de Coimbra no Século XV”, in Lusitania Sacra, $2^{a}$ Série, 17 (2005), Lisboa, pp. 183-225.

${ }^{30}$ Joaquim Chorão Lavajo, "Les Études Arabes dans l'Occident Médiéval”, in Actas do II Encontro sobre História Dominicana, Tomo III, Porto, Cartório Histórico Dominicano Português, 1987, pp. 217-238; Fr. António do Rosário, "Dominicanos e o Livro. Breves notas", in V Centenário do Livro Impresso em Portugal. 1487-1987. Colóquio sobre o Livro Antigo. Lisboa, 23-25 de Maio de 1988. Actas, Lisboa, Biblioteca Nacional, 1992, pp. 175-186.

Faculdade de Letras | Universidade de Coimbra 
debruçada sobre o pensamento escriturístico e filosófico. A Ordem conquistou, aliás, espíritos científicos, como se comprova do facto de alguns dos seus notáveis professos saírem das fileiras dos graduados em Medicina. O corpus legendário dominicano aponta preocupações médicas entre claustrais tão relevantes quanto o português S. Fr. Gil de Santarém e o próprio Santo Alberto Mago, ambos conotados, como dizíamos, com algum magismo cuja interpretação e dilucidação se encontram ainda por estudar pertinentemente.

A pregação ocupa lugar primacial na vida dominicana. Desse facto resultam as numerosas compilações de homílias que preencheram várias estantes das antigas bibliotecas eclesiásticas regulares e seculares. Fr. Paio de Coimbra, documentado já por 1228 e ainda em 1240, é o que mais se evidencia nos tempos fundacionais da Ordem em Portugal. O seu sermonário ${ }^{31}$ tem merecido a atenção competente de vários estudiosos. A proximidade entre os modelos constitucionais dos Cónegos Regrantes de Santo Agostinho, instalados em Coimbra, e o Convento de S. Domingos da mesma urbe pôde aprofundar-se ainda mais pela verificação de idêntica postura em matéria pastoral, para ambas as casas, assumindo importância o apostolado ad gentes, a pregação, a confissão, a liturgia solene dentro das igrejas monásticas mas também nas matrizes paroquiais sobre as quais tinham jurisdição ${ }^{32}$.

É na Coimbra do século XIII, e também mais tarde, na Coimbra da primeira metade de Quatrocentos, que encontramos indícios de uma estreita interacção entre a Canónica Regrante e os Mendicantes de S. Domingos desta cidade. A antiga biblioteca de Santa Cruz de Coimbra conservava cópias das Constituições dos Frades Pregadores (Biblioteca Pública Municipal do Porto [BPMP] - Santa Cruz, 54) e da Summa de poenitentia et de matrimonio (BPMP - Santa Cruz, 36) de Raimundo de Penhaforte e, ainda, da Legenda áurea, de Jacob de Voragine (BPMP - Santa Cruz 49) 33 .

${ }^{31}$ Bernardino Fernando da Costa Marques, Sermonário de Frei Paio de Coimbra. Edição e interpretação da estrutura e formas de pregação, Porto, Faculdade de Letras da Universidade do Porto, 1994.

${ }^{32}$ António do Rosário, "Letrados dominicanos em Portugal nos séculos XIII-XV", in Repertorio de Historia de las Ciencias Eclesiásticas en España, Vol. 7, (1979), Barcelona, pp. 593-594.

${ }^{33}$ Vd. Catálogo dos Códices da Livraria de Mão do Mosteiro de Santa Cruz de Coimbra na Biblioteca Pública Municipal do Porto (Coord. Aires Augusto Nascimento 
Abundaram nos conventos dominicanos portugueses, desde os seus primórdios, os códices manuscritos e, certamente, no devido tempo, os impressos. Anotemos, uma vez mais, que Infanta D. Mafalda, em 1256, lega ao "Monasterio fratrum Praedicatorum de Portu", uma cruz relicário em ouro com partículas do Santo Lenho do Senhor, que foi de Santa Helena, e de um osso de S. Brás, além de 200 morabitinos velhos, a serem aplicados "ad libros armarii". ${ }^{34}$

Ao Mosteiro de Alcobaça entregaram os frades de Santarém por penhor de uma cruz de cobre levantada nesta abacial estremenha, em 5 de Março de 1230, um "librum de vitis sanctorum", livro em pergaminho, "de grande antiguidade", com "quase tres palmos de comprido", segundo o autor da História de S. Domingos, que o $\mathrm{viu}^{35}$.

Uma bíblia deixada por um claustral domínico, do Convento de Barcelona, em S. Domingos de Santarém, decerto por finais do século XIII, mereceu a compensação ao Claustro catalão de um volume com o comentário de Santo Alberto Magno $(† 1280)$ às Sentenças e de um outro códice com obras de Dionísio, João Damasceno, Anselmo e outros autores ${ }^{36}$.

Manifestava-se útil ao claustro escalabitano a posse de uma bíblia, sempre de boa procura num ambiente pedagógico devotado ao estudo e reflexão da Sacra Pagina. Não menos relevante é o despojamento dos frades de Santarém, entregando aos catalães os manuscritos citados, que certamente não privavam o cenóbio de reter na sua biblioteca outras lições ou cópias dos títulos em causa. Perguntamo-nos, aliás, se eventualmente constaria dos manuscritos enviados a Barcelona o celebrado Cur Deus Homo, obra máxima de Anselmo de Cantuária, cujos capítulos 22 a 25 aparecem em forma de diálogo entre Anselmo e o seu discípulo Boso, refutando, marca de um renascimento cristão europeu undecentista, a teoria dos "direitos de domínio" da condenação, pelo

e José Francisco Meirinhos), Porto, Biblioteca Pública Municipal do Porto, 1997, passim.

${ }^{34}$ D. António Caetano de Sousa, Provas da História Genealogica..., Tomo I, pp. 39-43; Maria Helena Coelho, Arouca. Uma terra, um Mosteiro, uma Santa, Arouca, Real Irmandade da Rainha Santa Mafalda/Museu de Arte Sacra de Arouca, $2^{a}$ edição, 2005, pp. 82-85.

${ }^{35}$ História de S. Domingos, Parte I, Livro II, Cap ${ }^{\circ}$ V, p. 157.

${ }^{36}$ Citado por Raul de Almeida Rolo, Formação e Vida Intelectual de D. Frei Bartolomeu dos Mártires, Porto, 1977, p. 132-133. 
"direito da redenção" de uma Humanidade caída e que só um HomemDeus pôde satisfazer entregando-se pelos pecados de todos os homens.

Do sábio Alberto Magno, filósofo, teólogo e homem de pensamento científico-naturalista, professor nos claustros de Colónia e bispo de Ratisbona, cumpre reter a sua recuperação do aristotelismo, tornando-o (con)texto útil aos desideratos do pensamento cristão, abrindo, assim, o caminho à novidade tomista e a consagração já entre os universitários medievais, como "doctor universalis".

Mais antigos eram Dionísio e João Damasceno. O primeiro, talvez deva corresponder ao Pseudo-Dionísio, tratadista inspirado pelo neoplatonismo, entregando-se-lhe a autoria dos quatro tratados filosóficos "Os nomes divinos", "A Teologia mística", "A hierarquia celestial" e a "Hierarquia eclesiástica", textos bastante apreciados e copiados pelos letrados monges do Medievo. De S. João Damasceno, cujo nome contempla a celebrada cidade palestina, falecido em alongada velhice cerca de 754, exemplo ascético-monástico de consagração ao trabalho e à oração, poderemos aventar a hipótese de se conter no manuscrito escalabitano a Fonte do Conhecimento ou a sua antologia moral dos Sacra Parallela.

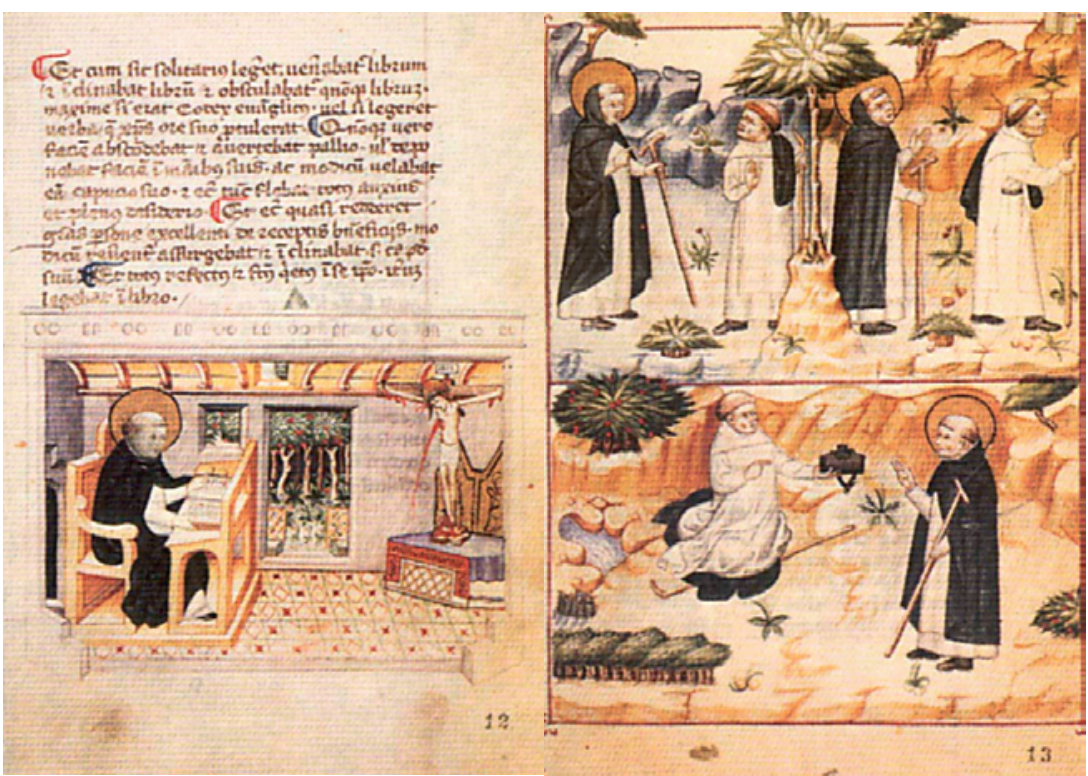

Oitavo e nono modos de orar de S. Domingos

(Roma, Bibl. Vaticana - Codex Rossianus, 3)

Faculdade de Letras | Universidade de Coimbra 
Teologia patrística antiga e nova teologia anselmiana, conhecimento enciclopédico, realista e aristotélico, textos ascético-morais, são todos eles um bom indicador das preocupações culturais que dominavam, nesse tempo, os frades dominicanos portugueses, que, decerto, souberam fazer aplicar em imagem esculpida ou pintada, como o podemos observar no magnífico Portal da Glória do Mosteiro da Batalha em cujas arquivoltas flamejantes se pressente a inspiração angélica do "Da hierarquia celestial" de Pseudo-Dionísio.

S. Domingos de Santarém, como os Conventos seus congéneres de Coimbra, Porto e Lisboa foram, desde os seus alvores, centros de formação intelectual da Ordem no nosso País. Juntar-se-lhes-iam, mais tarde, a Batalha, S. Domingos de Benfica e, decerto, Évora, entre os maiores. Em todos eles, seguramente, se encontrariam os livros adequados e necessários à vida intelectual e espiritual dos pregadores. Nestes, como nos demais claustros da Ordem, masculinos e femininos, existiam ainda preciosas bibliotecas litúrgicas.

Em 1322, D. Maria, viúva de D. João Simão, com capela funerária em S. Domingos de Santarém, deixa cem libras para "huum Domingal e pera huum Ofezial de Liçoens pera as Donas de Sam Domingos"37. No testamento de Rui Garcia [do Casal], datado de 19 de Julho de 1347, são deixados bens em Rio Maior para que a capela que fundara em S. Domingos de Santarém fosse suprida de tudo o necessário, enriquecendo-a, ainda, com a oferta de: "huum calez de prata com sa patena e duas galhetas de prata e os vestimentos e aalmitos e as sobrepelizas e frontãaes lavrados e os livros que mandei fazer pera a dita Capela e huum Santal novo e huum Misal de missas privadas, e huum Salteyro grande novo e huum Ofizial Domingal e Santal e huum caderno de Presses e huum Misal grande novo que he Santal e Domingal." 38

Os Frades de S. Domingos de Guimarães remetem ao recém-fundado Convento de S. Domingos de Vila Real, em 1426, um conjunto de livros de Ofício, citando-se um breviário dividido em dois volumes, copiado pela mão de Fr. Álvaro de Santa Justa, diversas Legendas dos Santos, um Saltério com aparato, um certo Testamento Novo, um Missal, sem notação, um certo Gradual, um Missal completo, pontuado,

${ }^{37}$ António do Rosário, "Pergaminhos dos Conventos Dominicanos. III Série: Elementos de interesse para a História da Arte. 2. Convento de S. Domingos de Santarém. Séc. XIV até 1350”, in Museu, IV Série, N² 2, 1994, pp. 125-184: 144.

${ }^{38}$ António do Rosário, Op. cit., p. 170. 
que só seria enviado a Vila Real depois de concluída uma cópia que do mesmo se ia fazendo no cenóbio vimaranense ${ }^{39}$.

A elevação do Mosteiro de Santa Maria da Vitória a panteão dinástico de Avis trouxe-lhe distinção no panorama domínico nacional e contribuiu seguramente para lhe definir uma vocação cultural de elite no seio da Província. A sua biblioteca, registada como unidade física individualizada já na década de 1470 - facto, lembremo-lo, raro na documentação coeva - viria a contar com belas e boas edições dos grandes humanistas italianos de Quatrocentos, citando-se, entre eles, Lorenzo Valla ( $\uparrow 1457)$, Jorge de Trebizonda $(\dagger 1486)$, Bartolomeu Facio, Giovanni Aurispa (†1459), António de Palermo (†1471) e Giovanni Pontano $(\dagger 1503)^{40}$.

No seu claustro, à entrada da Sala do Capítulo, onde em 1481 foram tumulados os restos mortais de D. Afonso V e, em 1491, os do malogrado Príncipe D. Afonso, receberam repouso eterno as ossadas de Fr. Justo Baldino, dominicano de origem itálica, pregador e embaixador na Corte de Borgonha, entrado ao serviço da Coroa de Portugal, em 1477, com a incumbência de traduzir para latim as crónicas dos reis de Avis, falecendo em 1493. Dessas traduções encomendadas pelo quinto Afonso, não sobejou rasto algum, mas é admissível a possibilidade de Fr. Justo Baldino ter alguma responsabilidade na autoria da hagiografia de D. Fernando, o Mártir Infante de Fez (†1443), pomposa e solenemente trasladado para o claustro batalhino em 1472 .

\section{5 - Manuscritos medievos de autores dominicanos em bibliotecas portuguesas contemporâneas.}

Assume particularíssima importância a biblioteca manuscrita, sobremodo, do Convento de Jesus de Aveiro, em cujos muros se recolheu a Infanta D. Joana, depois elevada ao altar dos santos, na qual se encontram tanto os textos da vida litúrgica da comunidade, como ainda obras de autoria local feminina, devendo ter-se por escribas de exímia qualidade as monjas que copiaram e decoraram muitos desses manuscritos pergamináceos. Do vizinho Convento de Nossa Senhora da Misericórdia de Aveiro, fundação patrocinada pelo Duque de Coimbra, o Infante D. Pedro, chega-nos um manuscrito quatrocentista de Sermones dominicales, cujo incipit afirma:

\footnotetext{
${ }^{39}$ Citado por Fr. António do Rosário, "Dominicanos e o Livro...", cit., p. 180.

${ }^{40}$ S. A. Gomes, Notícias e Memórias Paroquiais Setecentistas. 3. Batalha, Viseu,
} Ed. Palimage e Centro de História da Sociedade e da Cultura, 2005, p. 80. 
"Philosophia est diuinarum humanarumque rerum speculatio" (Biblioteca Nacional de Portugal [BNP] - IL 44).

Desses livros que tanto motivaram estes Frades de S. Domingos, poucos chegaram até nós e, dos que encontramos, raros ou nenhuns, com excepção de Aveiro, feitos em scriptoria dominicanos nacionais. Não impede esta asserção que manuscritos desta Ordem, provenientes de casas Além-Pirinéus, estejam hoje recolhidos nas casas-fortes de bibliotecas e de arquivos portugueses.

Dos exemplos que podemos aprontar, citaremos um grande volume, manuscrito do século XIII, com as Vitae Patrum Heremitarum, no qual lemos um antigo e primitivo pertence: "Iste liber est sororum ecclesiae beati Ludovici de Pissiaco", ou seja, oriundo das Dominicanas de S. Luís de Poissy, terra natal de S. Luís de França, hoje à guarda da Biblioteca Geral da Universidade de Coimbra (Biblioteca Geral da Universidade de Coimbra - Cofre, Ms. 23). Também desse Convento francês é originário Leccionarium ad usum Fratrum ordinis Praedicatorum, códice iluminado, já trecentista, hoje propriedade da Academia das Ciências de Lisboa (Manuscritos da Série Vermelha, $\mathrm{n}^{\mathrm{o}} 1$ ).

$\mathrm{Na}$ preciosa livraria de mão do Mosteiro de Alcobaça encontravam-se os Sermones de Sanctis, de Fr. Paio Pequeno, O. P. (†1240) (BNP, Alc. 5), o Chronicon Pontificum et Imperatorum e a Margarita Martiniana de Martinho de Polónia, arcebispo de Gnesen (†1325) (BNP, Alc. 16 e 276), os Sermones Dominicales, os Sermones de epistolis dominicarum e a Summa de vitiis de Guilherme Peraldo, O. P. (†1271) (BNP, Alc. 19, 60 e 196), as várias Summae de casibus e cópias das Decretales de Gregório IX que compilou, de S. Raimundo de Penhaforte (†1275) (BNP, Alc., 36, 197, 201, 271, 382), o Compendium theologicae veritatis, de Hugo Ripelino, O. P. (†1268) (BNP, Alc. 210, 376), os Sermones per circulum anni, de autor da Ordem dos Pregadores (BNP, Alc. 57), as Postillae super libros Sententiarum, as Postillae in Psalmos e as Postillae in Proverbia de Hugo de S. Caro, O. P. (†1263) (BNP, Alc. 147, 373, 374), a Expositio in Evangelium Mathei de Nicolau Gorrano, O. P. (†1295) (BNP, Alc. 264), o Speculum Sanctorale de Bernardo Guido, O. P. (†1331) (BNP, Alc. 447-449), a opera incontornável de S. Tomás de Aquino (†1274), Commentum in librum quartum Sententiarum (BNP, Alc. 261, 265), Summa Theologica (BNP, Alc. 266 e 269), Opuscula varia (BNP, Alc. 262), Summa contra gentiles (BNP, Alc. 268) e a Expositio super Regulam beatissimi patris Benedicti, compilação ou autoria do Cardeal João de Torquemada, O. P. $(† 1468)$ (BNP, Alc. 282) 
São de S. Tomás de Aquino dois outros manuscritos, um com os Opuscula varia (BNP - IL. 95) e outro com o Commentum in librum secundum Sententiarum (BNP - IL. 96). De Domingos Grenier, O. P. $(† 1342)$, encontra-se também em Portugal um códice em letra gótica com os Commentaria iuxta literalem et mysticum sensum in Sacra Biblia (BNP - IL. 114). Dois manuscritos trecentistas contendo a Legenda Aurea de Jacobus de Voragine, provenientes, um da antiga biblioteca alcobaciana e outro da Biblioteca dos Oratorianos das Necessidades, guardam-se hoje na Biblioteca Nacional (BNP, Alc. 39 e 40) e na Biblioteca da Ajuda (BPA, 52-XII-18), lembrando um dos auctores mais consagrados e populares das fileiras dominicanas. Um códice com o Compendium theologicae veritatis, de Hugo Ripelino, O. P., proveniente da Biblioteca dos Celestinos (O.S.B.) de Marcoussis (França), está hoje na Biblioteca Nacional de Lisboa (BNP, IL. 17).

De Bernardo Guido ( $\uparrow 1331$ ), existe um belo manuscrito iluminado com a Legenda Sancti Thomae de Aquino na Biblioteca Nacional (BNP, IL. 60) e, ainda, mas de Bernardo de Trilia, O. P. (Séc. XIII), a Postilla super Apocalypsin (BNP, IL. 89). Na mesma Biblioteca encontramos dois outros manuscritos dominicanos, um com a Summa de casibus poenitentiae de S. Raimundo de Penhaforte e outro das Distinctiones, de Nicolau Gorrano, O. P. (†1295), salvaguardados na mesma instituição, trazem nota de serem provenientes da colecção de Fr. Manuel do Cenáculo Vilas Boas, Bispo de Beja (BNP, IL. 27 e 28). Seis manuscritos do Speculum historiale de Vicente de Beauvais, O. P. (†1264), ricamente iluminados, estão igualmente depositados na Biblioteca Nacional de Portugal (BNP, IL. 125 a 128, 130 e 131). De Nicolau de Triveth, O. P. (†1328) encontramos a Expositio viginti librorum Titi Livii (BNP, IL. 134-135) e de Rainério de Pisa (O. P. (†ca. 1350) a Pantheologia (BNP, IL. 136-138).

É dominicano D. Fr. André Dias, o conhecido poeta português de Quatrocentos, falecido cerca de 1450, ao qual se deve o Livro de oraçoens em prosa e verso vulgar de louvores e excellências do Santissimi Nome de Jesus e dos milagres que Deus obrou, datado de 1435 (BNP, IL, 61). Anotação maior merecem as monjas da clausura de Jesus de Aveiro, dentro de cujos muros se afirmaram autoras e copistas de textos úteis à vida regular da comunidade avultando, entre todas, os nomes de Margarida Pinheiro e de Inês Dias. Aqui se recolheu, como escrevemos, a Princesa e futura Santa Joana de Aveiro, à qual não faltaram leituras espirituais, algumas delas, aliás, em impressos em letra de forma, para além de ter contado, algum tempo, com a presença do celebérrimo humanista Cataldo 
Parísio Sículo, proposto para o preceptorado do Infante D. Jorge, filho bastardo do rei D. João II e sobrinho da real princesa.

\section{6 - Ensino superior dominicano e as Universidades.}

Os frades mendicantes desempenharam um importante papel no ensino universitário de toda a Europa ${ }^{41}$. O Papa Nicolau IV, na sua bula de confirmação do Studium Generale português, de 1290, proíbe o ensino da Teologia neste novo claustro universitário, entregando antes a responsabilidade dessa docência aos mosteiros mendicantes de Lisboa, porque aí se havia estabelecido o Estudo. A passagem deste a Coimbra, entre 1308 e 1338 e, depois, entre 1354 e 1377, obrigou, naturalmente, à assunção por franciscanos e/ou dominicanos, residentes na cidade do Mondego, das funções magistrais do ensino teológico em conexão com os estudos universitários.

Ao Convento de S. Domingos de Coimbra se acolheria, em Quatrocentos, um elevado número de frades ungidos de ordens sacras na Sé de Coimbra nessa referida Centúria, ultrapassando mesmo os Franciscanos, realidade que nos parece dever conciliar-se com o facto do Claustro conimbricense domínico se estabelecer como studium maior de formação superior propedêutica ou mesmo quase-universitária, para ele sendo enviados os professos em fase de conclusão de estudos e de recepção do presbiterado ${ }^{42}$.

A Ordem de S. Domingos providenciou de forma sistemática uma formação intelectual exigente por parte dos seus professos. Nos finais do século XIII, funcionavam studia nos Conventos de Guimarães, Porto, Coimbra, Santarém, Lisboa, Évora e Elvas ${ }^{43}$. Sabemos que nos finais de Trezentos, tais estudos se viram acrescentados com a fundação dos claustros da Batalha e de Benfica.

O Capítulo Geral de Bolonha, celebrado em 1426, determinou que ninguém, na Ordem, se designasse por bacharel sem ter frequentado efectivamente uma universidade, obrigando-se qualquer um à frequência de curso quinquenal para promoção ao grau de mestre. Levantou este

${ }^{41}$ Vd. Jacques Verger, "Studia mendicanti e università", pp. 147-164.

${ }^{42}$ S. A Gomes, "Clérigos regulares nas Ordenações Sacras da Sé de Coimbra no Século XV”, in Lusitania Sacra, $2^{a}$ Série (17), 2005, pp. 183-225.

${ }^{43}$ Fr. Ramón Hernandez, Acta Capitulorum Provinciae Hispaniae. Pergaminos de actas de los Capitulos Provinciales del Siglo XIII de la Provincia Dominicana de España, Porto, Cartório Dominicano Português. Século XIII, Fasc. 2, 1984. 
Capítulo reservas ao reconhecimento do grau doutoral a quantos "studii in artibus more solito non fecerunt" da Hispania, recomendando-se a passagem dos estudantes portugueses e da "Universitatem Vallisoletane loco Parisius ad Studium".

Ao Convento de Lisboa era assignado, nesse ano de 1426, para regente de estudos, Fr. Pedro da Cruz, professor em Sagrada Teologia e Fr. Afonso Coubriense para ler Sentenças. Cometeu o mesmo Capítulo Geral a regência de Teologia nos Conventos portugueses a Fr. Gonçalo Mendes e a Fr. Pedro Sigerii [Soares (?)], ambos licenciados, determinando-se, finalmente, a entrada em estudos universitários de Fr. Gomes Martins e a aceitação do "Conventum de Auere [Aveiro], quem Dominus Petrus filius Illustrissimi Regis Portugallie edificavit" $"$. Em 1431, o novo Capítulo Geral confirma, em S. Domingos de Lisboa, a Mestre Fr. Pedro da Cruz na regência dos estudos do primeiro ano e a Mestre Manuel, para o segundo $\mathrm{ano}^{45}$.

Lembraremos, por outro lado, que Fr. Álvaro da Mota, designado pelo Capítulo Geral de Colmar de 1434, leitor de Sentenças em Valladolid, viria a ser nomeado por D. Afonso V, por carta de 30 de Setembro de 1450, reitor da Universidade estabelecida pelo Duque D. Pedro, em Coimbra. Sabemos que Fr. Álvaro da Mota se manteve activo em Coimbra pelo menos até cerca de 1455, pertencendo-lhe a tradução para português, datada desse ano de 1455, da Vida de D. Telo e Notícia da Fundação do Mosteiro de Santa Cruz de Coimbra, a partir dos manuscritos originais latinos guardados justamente pelos Crúzios ${ }^{46}$.

Não esquecemos que um dos intelectuais dominicanos de maior relevância no Quattrocento português foi Fr. João de Verba. Licenciado em Teologia, cedo aparece ao serviço da Casa Ducal de D. Pedro. Auxiliou-o, como se sabe, na redacção do conhecido Tratado da Virtuosa Benfeitoria, livro de ciência política em que se reflecte longa e profundamente a natureza do poder real e da governação dos soberanos face aos seus súbditos. Em 1423, o Infante D. Pedro súplica ao papa Martinho V, que nisso acede prontamente, a nomeação de Fr. João Verba para capelão pontifício e ainda que lhe fosse outorgada a comenda do

${ }^{44}$ Chartularium Universitatis Portugalensis (1288-1537) (Dir. A. Moreira de Sá), Vol. III (1409-1430), Lisboa, Instituto de Alta Cultura, 1969, Doc. 857.

${ }^{45}$ Chartularium..., Vol. IV, (1431-1445), Lisboa, 1970, Doc. 948.

${ }^{46}$ António do Rosário, "Letrados dominicanos em Portugal nos séculos XIIIXV”, in Repertorio de Historia de las Ciencias Eclesiásticas en España, Vol. 7, (1979), Barcelona, pp. 541-542.

Faculdade de Letras | Universidade de Coimbra 
Mosteiro de S. Jorge, a par de Coimbra, cujas rendas são avaliadas em 200 libras pequenas de Tours $^{47}$.

Entre os universitários dominicanos portugueses do século XV, nomeia-se Fr. Gonçalo Mendes, originário do Convento de Santarém, cursando a licenciatura de Teologia no Estudo Aquense (Aix), na Provença, solicitando as insígnias de magister em Teologia pela Universidade de Lisboa, em $1425^{48}$. É certamente este Fr. Gonçalo Mendes que virá a ser prelado da Província portuguesa da Ordem pelos anos de entre cerca de 1432 (em Janeiro de 1433 é já provincial) a cerca de 1445. Estanciou frequentemente no Mosteiro da Batalha pelos anos de 1435 a 1445, integrando a embaixada que o rei D. Duarte enviou ao Concílio de Basileia. Defendeu habilmente os interesses patrimoniais do Mosteiro batalhense na causa que o opôs a Santa Cruz de Coimbra, em 1438, e mereceu benesses régias atribuídas por carta de assentamento justamente em $1445^{49}$.

Em 1460, a comunidade dos Observantes de S. Domingos de Benfica solicitará ao Papa a dispensa de certos rigores quanto à abstinência de carne, excepção a aplicar especialmente aos mestres e peritos em Teologia aí residentes ${ }^{50}$. No Capítulo Geral de 1462, serão designados para as regências de estudos do Convento lisboeta a Fr. Airas da Vitória, para Sentenças no primeiro e segundo anos, "pro gradu et forma fr. Alphonsum Doctoriensem", e a Fr. Diogo de Coimbra, para os terceiro e quarto anos ${ }^{51}$. No Capítulo de 1478, nomeiam-se Fr. Rodrigo do Crato, professor de Teologia, para a Província portuguesa, a Fr. Afonso Velho, para regente da cátedra de Teologia em Lisboa, a Fr. Pedro Dias, de Évora, para leitura de Sentenças no primeiro ano e a Fr. Vasco de Évora, no segundo, e a Fr. Pedro Gil, do Porto, no terceiro ano ${ }^{52}$.

O Estudo universitário português encontrou, entre os Dominicanos, alguns dos seus lentes e, certamente, também alunos, mau grado o concurso que, à Universidade, faziam os claustros mendicantes. Na alvorada de 1500 , contudo, há uma certa tendência para enviar os estudantes mais promissores da Província à Universidade de Paris. Em

${ }^{47}$ Chartularium Universitatis Portugalensis (1288-1537) (Dir. A. Moreira de Sá), Vol. III (1409-1430), Lisboa, Instituto de Alta Cultura, 1969, Docs. 79 a 796.

${ }^{48}$ Chartularium Universitatis Portugalensis, Vol. III, Doc. 852.

${ }^{49}$ S. A. Gomes, O Mosteiro de Santa Maria da Vitória no Século XV, p. 256-260.

${ }^{50}$ Chartularium..., Vol. VI, (1456-1470), Lisboa, 1974, Doc. 1940.

${ }^{51}$ Chartularium..., Vol. VI, Doc. 2010.

${ }^{52}$ Chartularium..., Vol. VII (1471-1481), Lisboa, 1978, Doc. 2775. 
1511, D. Manuel I manda ao seu feitor na Flandres que dê a Fr. Manuel e a Fr. Gonçalo, frades pregadores portugueses, 15 cruzados a cada um, durante sete anos, tempo que se estimava adequado para estudar em Paris ${ }^{53}$.

\begin{tabular}{|c|c|c|}
\hline \multicolumn{3}{|c|}{ DOMINICANOS PORTUGUESES UNIVERSITÁRIOS EM QUATROCENTOS } \\
\hline Nome e ano & Estudos e funções & $\operatorname{Ref}^{n}$ \\
\hline $\begin{array}{l}\text { Fr. João de } \\
\text { Santa Justa: } \\
\quad 1410\end{array}$ & $\begin{array}{l}\text { Estudante em Oxford; provincial da Hispania em } \\
1417 .\end{array}$ & $\begin{array}{l}\text { Rosário, Letrados, } \\
\text { p. } 577\end{array}$ \\
\hline $\begin{array}{l}\text { Fr. Fernando } \\
\text { de Chelas: } \\
1413-1450\end{array}$ & $\begin{array}{l}\text { Bacharel em Sagrada Escritura; mestre de estudantes } \\
\text { em Colónia; prior de S. Domingos de Lisboa (1419); } \\
\text { professor de Filosofia e de Teologia na Universidade } \\
\text { de Lisboa. }\end{array}$ & $\begin{array}{l}\text { Rosário, Letrados, } \\
\text { p. } 563\end{array}$ \\
\hline $\begin{array}{l}\text { Fr. Pedro da } \\
\text { Cruz Sacra: } \\
1413-1431\end{array}$ & $\begin{array}{l}\text { Estudante em Paris (1413; mestre em Teologia e } \\
\text { professor; regente de Estudos em S. Domingos de } \\
\text { Lisboa (1431. }\end{array}$ & $\begin{array}{l}\text { Rosário, Letrados, } \\
\text { p. } 589\end{array}$ \\
\hline $\begin{array}{c}\text { Fr. Manuel } \\
\text { Lourenço } \\
\text { de Portugal: } \\
1414\end{array}$ & Doutor por Bolonha. & $\begin{array}{l}\text { Rosário, Letrados, } \\
\text { p. } 585\end{array}$ \\
\hline $\begin{array}{l}\text { Fr. Fernando } \\
\text { de Arroteia: } \\
1416-1453\end{array}$ & Pregador e confessor régio; vigário geral (1436). & $\begin{array}{l}\text { Rosário, Letrados, } \\
\text { p. } 561\end{array}$ \\
\hline $\begin{array}{l}\text { Fr. Álvaro de } \\
\text { Elvas: } \\
\text { 1421-1434 }\end{array}$ & $\begin{array}{l}\text { Leitor de Sentenças em Valladolid, pro forma et gradu; } \\
\text { mestre de estudantes. }\end{array}$ & $\begin{array}{l}\text { Rosário, letrados, } \\
\text { p. } 543 .\end{array}$ \\
\hline $\begin{array}{l}\text { Fr. Gomes } \\
\text { Martins de } \\
\text { Santarém: } \\
1426\end{array}$ & Leitor de Sentenças na Universidade de Valladolid. & $\begin{array}{l}\text { Rosário, Letrados, } \\
\text { p. } 569\end{array}$ \\
\hline $\begin{array}{l}\text { Fr. Afonso } \\
\text { de Coimbra: } \\
1426\end{array}$ & Leitor de Sentenças em S. Domingos de Lisboa. & $\begin{array}{l}\text { Rosário, Letrados, } \\
\text { p. } 537\end{array}$ \\
\hline $\begin{array}{l}\text { Fr. Martinho } \\
\text { Vasques: } \\
1426 \\
\end{array}$ & Lente na Universidade de Valladolid. & $\begin{array}{l}\text { Rosário, Letrados, } \\
\text { p. } 586\end{array}$ \\
\hline $\begin{array}{l}\text { Fr. Pedro } \\
\text { de Barbuda: } \\
1426\end{array}$ & Leitor de Sentenças em Valladolid. & $\begin{array}{l}\text { Rosário, Letrados, } \\
\text { p. } 589\end{array}$ \\
\hline
\end{tabular}

${ }^{53}$ TT - Corpo Cronológico, Parte 2a , Maço 26, Doc. 100.

Faculdade de Letras | Universidade de Coimbra 


\begin{tabular}{|c|c|c|}
\hline $\begin{array}{l}\text { Fr. Pedro } \\
\text { Soares } \\
\text { [“Sigerii”]: } \\
1426\end{array}$ & Leitor em S. Domingos de Lisboa. & $\begin{array}{l}\text { Rosário, Letrados, } \\
\text { p. } 591\end{array}$ \\
\hline $\begin{array}{c}\text { Fr. João de } \\
\text { Freitas: } 1436 \\
\end{array}$ & $\begin{array}{l}\text { Leitor em Valladolid; mestre em 1434; prior da Batalha } \\
\text { em } 1435 .\end{array}$ & $\begin{array}{l}\text { Rosário, Letrados, } \\
\text { p. } 575\end{array}$ \\
\hline $\begin{array}{l}\text { Fr. João de } \\
\text { Anta: } 1431\end{array}$ & Leitor de Sentenças em Valladolid. & $\begin{array}{l}\text { Rosário, Letrados, } \\
\text { p. } 574\end{array}$ \\
\hline $\begin{array}{l}\text { Fr. João de } \\
\text { Moura: } \\
1434-1440 \\
\end{array}$ & $\begin{array}{l}\text { Estudou em Paris; vigário geral da Observância; } \\
\text { confessor e conselheiro régio. }\end{array}$ & $\begin{array}{l}\text { Rosário, Letrados, } \\
\text { p. } 576 .\end{array}$ \\
\hline $\begin{array}{l}\text { Fr. Álvaro da } \\
\text { Mota: } \\
\text { 1434-1455 } \\
\end{array}$ & $\begin{array}{l}\text { Mestre em Teologia; leitor de Sentenças em Valladolid; } \\
\text { reitor da Universidade fundada em Coimbra (1450); } \\
\text { tradutor. }\end{array}$ & $\begin{array}{l}\text { Rosário, Letrados, } \\
\text { p. } 541\end{array}$ \\
\hline $\begin{array}{l}\text { Fr. João de } \\
\text { Freitas: } 1435 \\
\end{array}$ & Mestre em Teologia, prior do Mosteiro da Batalha & CUP, \\
\hline $\begin{array}{l}\text { Fr. Rodrigo } \\
\text { de Sintra: } \\
1436-1455\end{array}$ & $\begin{array}{l}\text { Bacharel em Teologia e confessor da Duquesa da } \\
\text { Borgonha; capelão pontifício (1455). }\end{array}$ & $\begin{array}{l}\text { CUP, IV, 1032, } \\
\text { 1033, 1316; } \\
\text { V, 1621, 1750; } \\
\text { Rosário, Letrados, } \\
\text { p. 593 }\end{array}$ \\
\hline $\begin{array}{l}\text { Fr. Gonçalo } \\
\text { [Mendes]: } \\
\text { 1436-1450 }\end{array}$ & $\begin{array}{l}\text { Teologia e provincial dos Dominicanos } \\
\text { ia de Portugal. }\end{array}$ & $\begin{array}{l}\text { CUP, IV, 1061; } \\
\text { V, 1525; Rosário, } \\
\text { Letrados, p. } 572\end{array}$ \\
\hline $\begin{array}{c}\text { Fr. Pedro } \\
\text { Fogaça: } 1436\end{array}$ & $\begin{array}{l}\text { Concessão do grau de licenciado em Teologia pela } \\
\text { Universidade de Lisboa. }\end{array}$ & $\begin{array}{l}\text { CUP, IV, 1061; } \\
\text { Rosário, Letrados, } \\
\text { p. } 590\end{array}$ \\
\hline $\begin{array}{l}\text { Fr. João de } \\
\text { Midões: } \\
\text { 1437-1445 } \\
\end{array}$ & $\begin{array}{l}\text { Doutor em Teologia e confessor da Duquesa da } \\
\text { Borgonha. }\end{array}$ & $\begin{array}{l}\text { CUP, IV, 1071; } \\
\text { Rosário, Letrados, } \\
\text { p. } 576\end{array}$ \\
\hline $\begin{array}{l}\text { Fr. João de } \\
\text { Sintra: } 1444\end{array}$ & $\begin{array}{l}\text { Bacharel; autorizado a andar em besta muar de sela e } \\
\text { freio por todo o Reino. }\end{array}$ & CUP, IV, 1346. \\
\hline $\begin{array}{l}\text { D. Fr. André } \\
\text { Dias: } \dagger 1448\end{array}$ & $\begin{array}{l}\text { Doutor e professor; bispo de Tabor (1415) e } \\
\text { de Mégara (1428), comendatário de S. João de } \\
\text { Alpendurada. }\end{array}$ & $\begin{array}{l}\text { Rosário, Letrados, } \\
\text { p. } 544\end{array}$ \\
\hline $\begin{array}{l}\text { Fr. Martinho } \\
\text { [da Aveiro]: } \\
\text { 1448-1466 }\end{array}$ & Doutor em Teologia e lente de Filosofia. & $\begin{array}{l}\text { Rosário, Letrados, } \\
\text { p. } 585\end{array}$ \\
\hline $\begin{array}{l}\text { Fr. Pedro de } \\
\text { S. Lourenço: } \\
1448 \\
\end{array}$ & $\begin{array}{l}\text { Mestre em Teologia; de S. Domingos de Benfica da } \\
\text { Observância: faculdade de confessar e absolver em } \\
\text { casos reservados aos Bispos. }\end{array}$ & 439. \\
\hline $\begin{array}{l}\text { Fr. Lourenço } \\
\text { Vasques de } \\
\text { Elvas: } 1448- \\
1452 \\
\end{array}$ & $\begin{array}{l}\text { Professor de Teologia e embaixador de D. Afonso } \\
\text { V ao Papa: faculdade de confessar e absolver casos } \\
\text { reservados aos bispos; comendatário do Mosteiro de } \\
\text { Pombeiro. }\end{array}$ & $\begin{array}{l}\text { CUP, V, } 1450, \\
\text { 1453, } 1637,1642, \\
\text { 1665; Rosário, } \\
\text { Letrados, p. } 583\end{array}$ \\
\hline
\end{tabular}




\begin{tabular}{|c|c|c|}
\hline $\begin{array}{l}\text { D. Fr. Gil } \\
\text { [Pires] de } \\
\text { Évora: } 1449- \\
1465\end{array}$ & $\begin{array}{l}\text { Confessor régio; bispo de Titópole (1459), doutor em } \\
\text { Decretos. }\end{array}$ & $\begin{array}{l}\text { Rosário, Letrados, } \\
\text { p. } 565\end{array}$ \\
\hline $\begin{array}{l}\text { Fr. Pedro } \\
\text { Bom [Fr. } \\
\text { Pedro da Cruz } \\
\text { Sacra (?)]: } \\
1449\end{array}$ & $\begin{array}{l}\text { Confessor do Infante D. Henrique; estudou doze anos } \\
\text { em Paris. }\end{array}$ & $\begin{array}{l}\text { Rosário, Letrados, } \\
\text { p. } 588\end{array}$ \\
\hline $\begin{array}{c}\text { Fr. Fernando } \\
\text { de Chelas: } \\
1450\end{array}$ & $\begin{array}{l}\text { Professor de Teologia e comendatário ocupante do } \\
\text { Mosteiro de Fonte Arcada havia dez anos. }\end{array}$ & $\begin{array}{l}\text { CUP, V, } 1525 \\
1526 ; \text { VI, } 1986\end{array}$ \\
\hline $\begin{array}{l}\text { Fr. Afonso } \\
\text { Velho: } \\
\text { 1448-1469 }\end{array}$ & $\begin{array}{l}\text { Mestre em Teologia, confessor do Infante D. Henrique } \\
\text { e embaixador ao Papa; autorizado a possuir dois } \\
\text { benefícios, mesmo que incompatíveis, incluindo um } \\
\text { Mosteiro da Ordem de Cister; indulto de escolher } \\
\text { confessor privativo; capelão pontifício, penitenciário } \\
\text { menor da Basílica de S. Pedro e pregador da Cruzada; } \\
\text { faculdade de conferir as insígnias de Mestre em } \\
\text { Teologia a quatro frades de Ordens Mendicantes } \\
\text { (1456). Indulto de poder dizer o Ofício divino segundo } \\
\text { o costume da Ordem Dominicana (1469). }\end{array}$ & $\begin{array}{l}\text { CUP, V, 1552; } \\
\text { VI, 1786, 1791, } \\
\text { 1794, 1797, 1798, } \\
\text { 1802, 1808, 2301; } \\
\text { Rosário, Letrados, } \\
\text { p. } 538\end{array}$ \\
\hline $\begin{array}{l}\text { Fr. João } \\
\text { Martins [de } \\
\text { Sintra (?)]: } \\
1450-1460\end{array}$ & $\begin{array}{l}\text { Mestre em Teologia e Provincial da Ordem em } \\
\text { Portugal: autorizado a andar em besta muar de sela } \\
\text { e freio; regalias em atenção aos trabalhos em prol da } \\
\text { Ordem, especialmente do Convento de Santa Maria } \\
\text { da Vitória ou Batalha (1458). Em 1460, o ministro } \\
\text { geral, provincial, definidores e capitulares do Capítulo } \\
\text { Provincial de Portugal pedem a revogação dos } \\
\text { privilégios que lhe tinham sido concedidos. }\end{array}$ & $\begin{array}{l}\text { CUP, V, } 1569, \\
1648 ; \text { VI, } 1870, \\
\text { 1938, 1939; } \\
\text { Rosário, Letrados, } \\
\text { p. } 578\end{array}$ \\
\hline $\begin{array}{l}\text { Fr. Nuno de } \\
\text { Elvas: } 1450\end{array}$ & Bacharel em Teologia. & CUP, V, 1572. \\
\hline $\begin{array}{l}\text { Fr. Diogo do } \\
\text { Porto: } 1452\end{array}$ & $\begin{array}{l}\text { Mestre em Teologia; prior de S. Domingos do Porto; } \\
\text { isenção contra as excomunhões do Bispo do Porto e } \\
\text { seus vigários que os perseguiam sob pretexto de se } \\
\text { negar a prestar contas de certos testamentos de que era } \\
\text { executor. }\end{array}$ & $\begin{array}{l}\text { CUP, V, 1663, } \\
1664 .\end{array}$ \\
\hline $\begin{array}{l}\text { Fr. João de } \\
\text { Laureto: } \\
1452-1460\end{array}$ & $\begin{array}{l}\text { Bacharel em Teologia: isenção contra as excomunhões } \\
\text { do Bispo do Porto e seus vigários que os perseguiam } \\
\text { sob pretexto de se negar a prestar contas de certos } \\
\text { testamentos de que era executor. }\end{array}$ & $\begin{array}{l}\text { CUP, V, 1663, } \\
\text { 1664; Rosário, } \\
\text { Letrados, p. } 576\end{array}$ \\
\hline $\begin{array}{l}\text { D. Fr. Estêvão } \\
\text { Cão [ou de } \\
\text { Portugal]: } \\
1458 \\
\end{array}$ & $\begin{array}{l}\text { Bacharel em Teologia: nomeado bispo Foliarum } \\
\text { (Foliense). }\end{array}$ & $\begin{array}{l}\text { CUP, VI, } 1869 \\
1939\end{array}$ \\
\hline $\begin{array}{l}\text { D. Fr. Gil de } \\
\text { Évora: } 1459\end{array}$ & $\begin{array}{l}\text { Mestre em Teologia: promovido à Sé episcopal de } \\
\text { Titopole. }\end{array}$ & CUP, VI, 1912. \\
\hline
\end{tabular}




\begin{tabular}{|c|c|c|}
\hline $\begin{array}{l}\text { Fr. Fernando } \\
\text { de Oliveira: } \\
\text { 1460-1493 }\end{array}$ & $\begin{array}{l}\text { Doutor e prior em S. Domingos do Porto, depois em } \\
\text { Coimbra (1493); leitor de Sentenças em qualquer } \\
\text { Estudo (1493). }\end{array}$ & $\begin{array}{l}\text { Rosário, Letrados, } \\
\text { p. } 564\end{array}$ \\
\hline $\begin{array}{l}\text { Fr. João de } \\
\text { Baltar: } 1460- \\
1480\end{array}$ & $\begin{array}{l}\text { Doutor e professor de Teologia em S. Domingos do } \\
\text { Porto e em S. Domingos de Vila Real. }\end{array}$ & $\begin{array}{l}\text { Rosário, Letrados, } \\
\text { p. } 574\end{array}$ \\
\hline $\begin{array}{c}\text { Fr. João } \\
\text { Lopes: } 1461\end{array}$ & $\begin{array}{l}\text { Professor de Teologia: indulto de escolher confessor e } \\
\text { absolvição em casos reservados à Santa Sé. }\end{array}$ & $\begin{array}{l}\text { CUP, VI, 1964, } \\
\text { 1965; Rosário, } \\
\text { Letrados, p. } 577 \\
\end{array}$ \\
\hline $\begin{array}{l}\text { Fr. Diogo } \\
\text { de Coimbra: } \\
1462-1492\end{array}$ & $\begin{array}{l}\text { Bacharel em Teologia: indulto de obter um terceiro } \\
\text { benefício incompatível; leitor de Sentenças em } \\
\text { S. Domingos de Lisboa; pregador, havia } 12 \text { anos, } \\
\text { na presença de D. Afonso V e do Príncipe D. João; } \\
\text { examinador. }\end{array}$ & $\begin{array}{l}\text { CUP, VII, 2864, } \\
\text { 2865; Rosário, } \\
\text { Letrados, p. } 558\end{array}$ \\
\hline $\begin{array}{l}\text { Fr. Afonso de } \\
\text { Lorvão: } 1462 \\
\end{array}$ & $\begin{array}{l}\text { Doutor (segundo o costume de Portugal) em Teologia: } \\
\text { concessão de benefício eclesiástico. }\end{array}$ & $\begin{array}{l}\text { CUP, VI, 1993- } \\
1996 .\end{array}$ \\
\hline Fr. Aires & $\begin{array}{l}\text { Mestre em Teologia, regente de Estudos em Lisboa, } \\
\text { definidor capitular e beneficiário de privilégios } \\
\text { pontifícios. }\end{array}$ & $\begin{array}{l}\text { CUP, VI, 2011; } \\
\text { Rosário, Letrados, } \\
\text { p. } 541 \\
\end{array}$ \\
\hline $\begin{array}{l}\text { Fr. Brás de } \\
\text { Évora: } 1474\end{array}$ & $\begin{array}{l}\text { Doutor e leitor de Sentenças em S. Domingos de } \\
\text { Lisboa. }\end{array}$ & $\begin{array}{l}\text { Rosário, Letrados, } \\
\text { p. } 557\end{array}$ \\
\hline $\begin{array}{l}\text { Fr. Rodrigo } \\
\text { do Crato: } \\
1475-1477 \\
\end{array}$ & $\begin{array}{l}\text { Leitor de Sentenças em Aix (França) (1475), depois } \\
\text { em Paris (1477). }\end{array}$ & $\begin{array}{l}\text { Rosário, Letrados, } \\
\text { p. } 593\end{array}$ \\
\hline $\begin{array}{l}\text { Fr. Fernando } \\
\text { de Lisboa: } \\
1476\end{array}$ & $\begin{array}{l}\text { Bacharel em Teologia que estudara no Estudo de } \\
\text { Valladolid: recebe indulto para obter as insígnias } \\
\text { doutorais em Teologia, com todos os privilégios dos } \\
\text { Mestres da Universidade de Lisboa. }\end{array}$ & CUP, VII, 2661. \\
\hline $\begin{array}{l}\text { Fr. Pedro } \\
\text { Dias: } \\
1478-1495\end{array}$ & $\begin{array}{l}\text { Reformador conventual, visitador, embaixador; } \\
\text { bacharel e pregador; leitor de Sentenças na } \\
\text { Universidade de Lisboa (1481). }\end{array}$ & $\begin{array}{l}\text { Rosário, Letrados, } \\
\text { p. } 590\end{array}$ \\
\hline $\begin{array}{l}\text { Fr. Pedro Gil } \\
\text { [Fr. Pedro } \\
\text { Dias (?)]: } \\
1478\end{array}$ & Leitor de Sentenças em S. Domingos de Lisboa. & $\begin{array}{l}\text { Rosário, Letrados, } \\
\text { p. } 590\end{array}$ \\
\hline $\begin{array}{c}\text { Fr. Justo } \\
\text { Baldino: } \\
\text { 1479ca.-1493 } \\
\end{array}$ & $\begin{array}{l}\text { Doutor in utroque; humanista; tradutor; bispo de Ceuta } \\
\text { (1479). }\end{array}$ & $\begin{array}{l}\text { Rosário, Letrados, } \\
\text { p. } 580\end{array}$ \\
\hline $\begin{array}{l}\text { Fr. João de } \\
\text { Lisboa: } 1475- \\
1481\end{array}$ & $\begin{array}{l}\text { Bacharel e vigário do Convento de Lisboa; mestre e } \\
\text { reformador dos Conventos de Lisboa e de Santarém; } \\
\text { definidor provincial }\end{array}$ & $\begin{array}{l}\text { Rosário, Letrados, } \\
\text { p. } 576\end{array}$ \\
\hline $\begin{array}{c}\text { Fr. João } \\
\text { Correia: } 1476\end{array}$ & Bacharel em Teologia. & CUP, VII, 2683. \\
\hline $\begin{array}{l}\text { Fr. Afonso de } \\
\text { Évora: } 1481- \\
\quad 1494\end{array}$ & Doutor, pregador e beneficiário de graças da Ordem. & $\begin{array}{l}\text { Rosário, Letrados, } \\
\text { p. } 537\end{array}$ \\
\hline
\end{tabular}




\begin{tabular}{|c|c|c|}
\hline $\begin{array}{l}\text { Fr. Diogo } \\
\text { Velho: } 1481\end{array}$ & $\begin{array}{l}\text { Leitor de Sentenças na Universidade; prior do } \\
\text { Convento de Évora em } 1488 \text { com licença para se } \\
\text { doutorar em qualquer universidade }\end{array}$ & $\begin{array}{l}\text { Rosário, Letrados, } \\
\text { p. } 558\end{array}$ \\
\hline $\begin{array}{l}\text { Fr. Afonso } \\
\text { Garcia: } 1489\end{array}$ & $\begin{array}{l}\text { Bacharel, definidor do Capítulo Geral e prior de } \mathrm{S} \text {. } \\
\text { Domingos de Elvas. }\end{array}$ & $\begin{array}{l}\text { Rosário, Letrados, } \\
\text { p. } 538\end{array}$ \\
\hline $\begin{array}{l}\text { Fr. Álvaro da } \\
\text { Torre: } 1491\end{array}$ & $\begin{array}{l}\text { Professor de Teologia e pregador, várias vezes, } \\
\text { perante o Rei de Portugal, tendo empreendido viagens } \\
\text { em favor da Fé cristã. }\end{array}$ & $\begin{array}{l}\text { CUP, VIII, 3439; } \\
\text { Rosário, Letrados, } \\
\text { p. } 543\end{array}$ \\
\hline $\begin{array}{l}\text { Fr. João de } \\
\text { Aveiro: } 1493- \\
1495\end{array}$ & Graduado em teologia e visitador. & $\begin{array}{l}\text { Rosário, Letrados, } \\
\text { p. } 374\end{array}$ \\
\hline $\begin{array}{l}\text { Fr. Pedro de } \\
\text { Lourosa: } 1496\end{array}$ & $\begin{array}{l}\text { Mestre em Teologia: incorporado, por concessão do } \\
\text { Geral, Fr. Joaquim Veneto, no Convento de Lisboa, } \\
\text { como se fosse seu filho, e na administração da Capela } \\
\text { de Nossa Senhora da Escada do dito Convento. }\end{array}$ & CUP, VIII, 3618. \\
\hline $\begin{array}{l}\text { Fr. Anselmo } \\
\text { Hispano: } 1497\end{array}$ & $\begin{array}{l}\text { Estudante durante vários anos de Teologia: indulto } \\
\text { de receber grau académico de Mestre das mãos do } \\
\text { Chanceler da Universidade de Paris, com isenção de o } \\
\text { receber nessa Universidade, por motivos de pobreza. }\end{array}$ & CUP, VIII, 3701. \\
\hline $\begin{array}{l}\text { Fr. Heitor: } \\
1499\end{array}$ & $\begin{array}{l}\text { Autorizado pelo geral, Fr. Joaquim Turiano, a } \\
\text { permanecer durante } 12 \text { anos no Estudo Geral de Lisboa } \\
\text { à custa do próprio pai, a fim de obter confirmação } \\
\text { apostólica da licença de residir nesse Estudo durante } \\
\text { cinco anos. }\end{array}$ & CUP, VIII, 3819. \\
\hline
\end{tabular}

Na mesma Feitoria, em 1514, receberiam Fr. Gonçalo Oliveira e Fr. Manuel Estaço, religiosos do mesmo hábito, 30 cruzados anuais, enquanto estudassem na capital francesa ${ }^{54}$, o que efectivamente lhes foi atestado por Mestre João, bedel do Convento de S. Domingos de Paris ${ }^{55}$. Em 1517, frequentava os estudos parisinos, com mesada de 15 cruzados, o bacharel Fr. Diogo Nogueira, ocupante de vaga, por renúncia, de Fr. Ascenso, seu companheiro ${ }^{56}$. No ano seguinte, pagavase a mesada a Fr. Gonçalo de Aveiro, para sustento do seu estudo nessa cidade $^{57}$. Em 1531, Fr. Álvaro de Lisboa foi nomeado lente substituto da cadeira de Sentenças nessa Universidade, louvando o Convento dominicano de Paris ao rei D. João III pelo amor que revelava ter para com os homens de letras ${ }^{58}$.

${ }^{54}$ TT - Corpo Cronológico, Parte 2a ${ }^{\mathrm{a}}$ M 37, Docs. 201 e 208.

${ }^{55}$ TT - Corpo Cronológico, Parte 2 $2^{\mathrm{a}}, \mathrm{M}^{\mathrm{o}} 37$, Doc. 213.

${ }^{56}$ TT - Corpo Cronológico, Parte $2^{\mathrm{a}}, \mathrm{M}^{\mathrm{o}} 69$, Doc. 84.

${ }^{57}$ TT - Corpo Cronológico, Parte $2^{\mathrm{a}}, \mathrm{M}^{\mathrm{o}} 74$, Doc. 26.

${ }^{58}$ TT - Corpo Cronológico, Parte $1^{\mathrm{a}}$, Maço 46, Doc. 100.

Faculdade de Letras | Universidade de Coimbra 
A abertura do Colégio de S. Tomás em Lisboa, em $1516^{59}$, endogeneizará, de algum modo, o problema da formação intelectual e teológica superior dos professos da Ordem em Portugal, reduzindo-se, desse modo, os incentivos às partidas dos religiosos da Ordem para Paris em benefício da continuidade dessa formação em território nacional ${ }^{60}$.

\section{7 - Outros desempenhos culturais dominicanos: a memória histórica, a pastoral e a vida quotidiana.}

No Livro de Aniversários do Convento de S. Domingos de Lisboa ${ }^{61}$, encontramos renovado testemunho da vida intelectual dominicana portuguesa. As Breves Crónicas que aí inscreveu Fr. Afonso de Alfama, demonstram muito bem a pluralidade da historiografia portuguesa de meados de Quatrocentos, quando pontificava, na Corte de D. Afonso V, o vulto de Gomes Eanes de Zurara. Mas este precioso manuscrito deixa entrever a vida cultural do claustro domínico olisiponense por várias faces. Texto instrumental da vida litúrgica, abre com tabelas de cômputo para achar as festas móveis e a pauta das mesmas para os anos de 1441 a 1484 .

Segue-se-lhes o necrológio, apontando os nomes dos benfeitores do Convento, as capelas e túmulos em que repousavam. Várias eram as capelas erguidas no edifício monástico. $\mathrm{Na}$ sala capitular jazia o fidalgo Airas Gomes da Silva, entre outros de menor nome, enquanto Mestre Vasco, físico, fora enterrado no meio da igreja. Na capela de $\mathrm{S}$. Martinho, ante do altar de Santa Maria-a-Formosa, no claustro junto ao "moimento alto", à porta do dormitório, nos moimentos do alpendre, à entrada da porta da claustra para a igreja, nos túmulos abaixo da escada de Santa Maria da Escada, a par do altar de Jesus - onde jazeria o "Reverendus magister Andreas excelentissimus predicator et fundator

${ }^{59}$ Sebastião da Silva Dias, "Os Dominicanos e a Filosofia em Portugal no Século XVI”, in Actas do II Encontro sobre História Dominicana, Vol. III/2, Porto, 1986; S. A. Gomes, "O Mosteiro de Santa Maria da Vitória no Professorado de D. Frei Bartolomeu dos Mártires (1538-1552) ”, in Actas do IV Centenário da Morte de D. Frei Bartolomeu dos Mártires - Congresso Internacional, Fátima, Movimento Bartolomeano, 1994, pp. 59-224.

${ }^{60}$ Em 27 de Julho de 1529, frequentavam, este Colégio de S. Tomás, 20 colegiais. (TT - Corpo Cronológico, Parte 2a, Maço 157, Doc. 55).

${ }^{61} \mathrm{TT}-$ Convento de S. Domingos de Lisboa, Livro 73; publicado por A. Borges Nunes e Fr. António do Rosário, 
confratrie et altaris domini nostri Iesu" - , nos moimentos de fora, na capela dos Bretões, na dos Palhavã, na de D. Maria de Aboim, na de D. Gonçalo Vasques de Melo, na de D. Gil Alma, bispo in partibus saído das fileiras dominicanas e auxiliar, entre outras, na Diocese de Coimbra onde celebrou frequentemente ordens sacras, assinalavam-se numerosas sepulturas, entre as quais a de Fr. Álvaro de Elvas, doutor e prior do Convento, falecido em 1453, e, ainda, Fr. Lourenço, "meestre dos orgõos", finado em 1449, e testemunha da evolução da prática musical que, em S. Domingos de Lisboa como também na Batalha e, decerto, nos demais conventos da Ordem, se ia praticando e ouvindo. Não será redundante, aqui, referir que foi um frade dominicano que se deslocou, por 1431, ao Mosteiro de Alcobaça, a fim de nele fazer certos órgãos para a igreja desta abacial ${ }^{62}$. "Órgãos de anjos" deveriam acompanhar a celebração das missas cantadas e oficiadas de S. Miguel e de S. Jerónimo (29 e 30 de Setembro) instituídas pelo rei D. Manuel I na Batalha, em $1499^{63}$.

Bretões e ingleses tinham nos Dominicanos de Lisboa os seus capelães. Em 1472, o rei D. Afonso V confirmou o Compromisso da Confraria dos Mercadores Borgonheses e Flamengos de Lisboa, instituída no Mosteiro de S. Domingos dessa cidade, com capela no altar de Santa Cruz, se bem que a relação destes naturais do Ducado borgonhês com os dominicanos lisboetas fosse bem mais antiga. De facto, atesta-se já um Fr. Nicolau, "capelanus angricorum" que "obiit morte subitanea" em 1 de Dezembro de 1449.

Sucedem-se inscrições de profissões de frades, recebidos na Ordem em dias festivos como o S. Miguel de 1433, os dias da Ascensão e de S. Domingos de 1438, o dia de S. Pedro Mártir, o da Assunção de Nossa Senhora, o da trasladação "de nosso padre Sam Domingos", de 1445, o Pentecostes de 1461 e de 1465, o dia da Trindade em que Fr. Antão e seus dois irmãos receberam o hábito "e seu padre e madre nos deram boo jantar a modo de missa nova afruenter" ${ }^{64}$. Recolheram-se, ainda,

${ }^{62}$ Iria Gonçalves, O Património do Mosteiro de Alcobaça nos Séculos XIV e XV, Lisboa, Faculdade de Ciências Sociais e Humanas da Universidade Nova de Lisboa, 1989, p. 333.

${ }^{63} \mathrm{~S}$. A. Gomes, O Mosteiro de Santa Maria da Vitória no Século XV, Coimbra, 1990, p. 362.

${ }^{64}$ Cód. 73, SDL. ANTT. Liber Anniversariorum / Livro dos Aniversários. Breves Crónicas pelo coevo Fr. Afonso de Alfama, op. (Leitura paleográfica de Eduardo Borges Nunes; amanho gráfico e tradução das partes latinas de Fr. António do Rosário), Porto, Arquivo Histórico Dominicano Português, 1995, p. 15.

Faculdade de Letras | Universidade de Coimbra 
a este Convento outros dominicanos de origem estrangeira, como Fr. Gonçalo de Segóvia e Fr. Pedro dos Santos, castelhano, recordando-nos estarmos perante uma Ordem efectivamente mendicante e em que muitos dos seus professos peregrinavam por longas distâncias. Do Convento lisboeta sairiam para o de Ceuta, em 1415, segundo garante Fr. Afonso de Alfama, Fr. Gil Mendes, Fr. Pedro, pintor, e Fr. Rogel, inglês, palavras bem reveladoras da pluralidade de línguas e de competências culturais e artísticas que os muros de S. Domingos de Lisboa conheciam ${ }^{65}$.

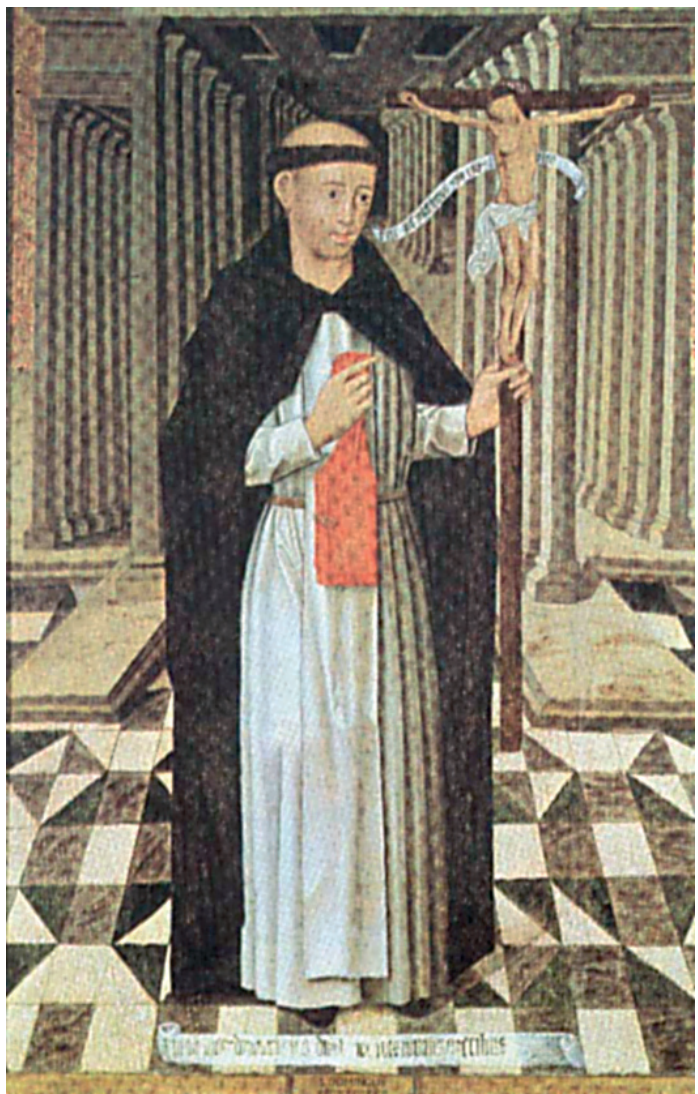

S. Domingos (ca. 1500)

(Museu de Aveiro)

${ }^{65}$ Cód. 73, p. 25. 
Vêm, de imediato, as Breves Crónicas de Fr. Afonso de Alfama, para, de imediato, dar lugar à retomada do obituários dos frades - de que se destaca Fr. Manuel, mestre em teologia e doutor em Física, falecido a 2 de Maio de 1438 "et sepultus est cum magistro Martino" e demais benfeitores. Grande perda recebeu o Mosteiro com o dilúvio de 16 de Setembro de 1488, que "deribou a parede da nossa orta pequena E nos alagou todo o mosteyro e logares huã braça craveyra $E$ logares menos E foy mui grande estruiçom na Igreja crasta e cabidoo E em todalas outras oficinas de que este mosteyro recebeo mui grande perda." 66

Uma brevíssima visita a S. Domingos de Santarém permitir-nos-ia encontrar uma paisagem não muito distinta da que se observava no claustro lisboeta. Fr. Luís de Sousa, na sua História de S. Domingos, descreve muito expressivamente as pinturas murais medievas que povoavam o alpendre, igreja, claustro, sala capitular e outros cómodos desta casa.

Debaixo das suas góticas abóbadas, pedras tumulares recordavam frades distintos da ordem que ali tinham recebido tumulação. "Hic jacet Domnus Frater Dominicus Veeyra reuerendus Doctor Ordinis Praedicatorum, qui bona senectute plenus dierum, et sapientiae obijt in Domino in Vigilia Natalia Aera M. CCC. LX', lia-se numa dessas lápides, enquanto outras lembravam, em latim ou já em português, que: "Hic iacet Frater Gonçaluus de Calciata Prior Prouincialis Ordinis Praedicatorum, qui obijt anno Domini M. CCC. LX", "Aqui jaz Mestre Gonçalo que foi provincial da Ordem de São Domingos por dezoito annos, e Prior do Mosteiro da Vitoria por dez annos. Alma sua folga em paz. E finou Aera Domini M. CCCC. XXXXVIII, aos XVIII dias de Outubro"67, entre outras, todas traduzindo uma cultura educacional em que o testemunho individual, o exemplum pedagógica e tendencialmente hagiográfico, a imagem e o verbo feitos pedra para perpétua memória da comunidade religiosa. Topoi que, ainda hoje, encontramos nessas nobres casas góticas, dentro e fora de Portugal, a começar por essa arca matricial da Ordem que é Santa Sabina de Roma.

Tiveram, ainda, os Dominicanos uma relevante acção na propalação de devoções como a do Nome de Jesus e a da Virgem do Rosário. Estas devoções inspirarão o aparecimento de confrarias laicais em quase

\footnotetext{
${ }^{66}$ Cód. 73, p. 17.

${ }^{67}$ Citados por Fr. Luís de Sousa, Historia de S. Domingos, Parte I, Livro II, Cap ${ }^{\circ}$ XXXIX, p. 263.

Faculdade de Letras | Universidade de Coimbra
} 
todos os conventos da Ordem em Portugal, associando-se estas às mais antigas e tradicionais confrarias dedicadas ao orago de S. Domingos ${ }^{68}$.

Em S. Domingos de Coimbra, já em 1494 se erguia confraria com altar e imagem de Nossa Senhora do Rosário, fundada pelo ourives Afonso Pais e pelo escrivão da fazenda Henrique de Parada. Outros altares aqui existiram dedicados a S. Frei Gil, Santa Iria e Santa Catarina ${ }^{69}$. No Mosteiro da Batalha, contavam-se altares com imagens de S. Gonçalo, Santa Bárbara, Ascensão, Nossa Senhora do Rosário, Nossa Senhora da Piedade, S. Sebastião e de Jesus, enquanto na Capela do Fundador, as capelas recebiam por oragos as intitulações de S. Miguel, do Infante Mártir D. Fernando, de S. João Baptista e da Assunção de Nossa Senhora, ficando à primitiva igreja de Santa Mariaa-Velha os oragos dos altares de Santa Maria da Vitória, de S. Jorge, de S. Domingos, do Espírito Santo e do Nome de Jesus ${ }^{70}$.

Em S. Domingos do Porto, contavam-se os altares de S. Frei Gil, Santa Catarina de Sena, - imagem principal ladeada, bem na continuidade do que encontraríamos em fólios iluminados de Livros de Horas do tempo, por Santa Luzia e Santa Apolónia - de Santo André, de Nossa Senhora do Loreto, no Capítulo, de Santo André, de Nossa Senhora, a Flamenga, de Jesus (1428) e da Santíssima Trindade, entre outros $^{71}$.

${ }^{68}$ Vd. Gilles Gerard Meersseman, Ordo Fraternitatis. Confraternite e Pietà dei Laici nel Medioevo, 3 Vols., Roma, Herder Editrice e Libreria, 1977, passim; José Marques, "A Confraria de S. Domingos de Guimarães (1498)", in Actas do II Encontro sobre História Dominicana, Tomo II, Porto, Arquivo Histórico Dominicano Português, 1986, pp. 55-80; S. A. Gomes, "Notas e Documentos Sobre as Confrarias Portuguesas Entre o Fim da Idade Média e o Século XVII: o Protagonismo Dominicano de $\mathrm{St}^{\mathrm{a}}$ Maria da Vitória", in Lusitania Sacra, 2a série, Tomo 7, Confrarias, Religiosidade e Sociabilidade, Lisboa, Centro de Estudos de História Religiosa - Universidade Católica Portuguesa, 1995, pp. 89-150; Idem, O Livro do Compromisso da Confraria e Hospital de Santa Maria da Vitória da Batalha (1427-1544), Leiria, Magno, 2002.

${ }^{69}$ Maria Helena da Cruz Coelho e João José Cunha Matos, Op. cit., p. 8.

${ }^{70} \mathrm{~S}$. A. Gomes, O Mosteiro de Santa Maria da Vitória no Século XV, Coimbra, 1990, p. 358; Idem, Vésperas Batalhinas. Estudos de História e Artes, Leiria, edições Magno, 1997, passim.

${ }^{71}$ Albertina da Conceição Machado da Silva Barbosa, Capelas e Aniversários do Mosteiro de S. Domingos do Porto no Séc. XV, (Dissertação de Mestrado; policopiada), Porto, Faculdade de Letras da Universidade do Porto, 1995, pp. 60-63, 73-77, 91-92, $101,110,128$. 
Também nos nomes de profissão destes descortinamos maioritariamente a tradição denominativa pela referência ao lugar de nascimento ou de origem do frade, conquanto se vá manifestando, mais para os finais da Idade Média, a moda da adopção de nome simbólico do santoral domínico. Em Coimbra, cerca de 1383, por exemplo, o filho de Estêvão de Cerveira professou no Convento local com o nome de Fr. Pedro Mártir ${ }^{72}$, mas estamos perante um caso com algum carácter excepcional.

Já os nomes dos novos conventos, fundados entre finais do século XIV e o declinar do XV, indicam a hegemonia das devoções crísticas (Corpus Christi de Vila Nova de Gaia, Santíssimo Salvador de Lisboa, Jesus de Aveiro) ou relativas à vida de Santa Maria (Nossa Senhora da Misericórdia de Aveiro, Nossa Senhora da Consolação de Abrantes, Nossa Senhora da Luz de Pedrógão Grande, Santa Ana de Leiria) ou do próprio S. Domingos (S. Domingos de Benfica, S. Domingos de Vila Real, S. Domingos de Azeitão), conquanto Nossa Senhora da Escada se mantenha santuário maior nas rotas espirituais dos portugueses dessas épocas.

Curaram muito, os medievos pregadores portugueses, da memória dos mortos seus benfeitores em vida. Os laços de solidariedade tecidos em vida, não prescreviam com o momento da morte. Mas não há dúvida, também, de que os Dominicanos não se limitavam a ficar encerrados nos seus claustros. Uma atitude pastoral activa, mendicante, levava-os ao apostolado em áreas regionais. Os de Coimbra pregavam na Sé desta cidade, mas tinham também missões em Viseu e por toda a região mondeguina.

Os de Lisboa encarregavam-se das áreas mais directamente sujeitas à influência olisiponense, sobretudo Sintra, Alenquer, Torres Vedras. Os de Santarém são alvo de reconhecimento de gentes de Óbidos, de Abrandes e mesmo de Leiria, até que a casa da Batalha os substitui nesta zona da bacia hidrográfica do rio Lis. Os do Porto, naturalmente, como os de Guimarães, Vila Real, Évora ou Elvas, como ainda novas casas na cintura de Lisboa (Benfica e Azeitão), não podem ter deixado de percorrer os caminhos das vilas e aldeias desses territórios.

Foi esse apostolado, reconhecidamente, que os levou à fundação de novos conventos e ao reconhecimento do seu papel numa sociedade profundamente marcada pela sensibilidade do religioso e abertura aos mistérios sobrenaturais, como era a sociedade portuguesa medieval, em cujo seio, como vimos, a Ordem de S. Domingos desempenhou um papel espiritual e cultural plural.

${ }^{72}$ Maria Helena da Cruz Coelho e João José Cunha Matos, Op. cit., p. 7. 